\section{Ankara Üniversitesi Eğitim Bilimleri \\ Fakültesi Özel Eğitim Dergisi}

$2021,22(4), 1025-1055$

\section{DERLEME}

Gönderim Tarihi: 02.04.20

Kabul Tarihi: 19.01.21

Erken Görünüm: 29.01.21

\title{
Matematik Öğrenme Güçlüğü Yaşayan Öğrencilere Yönelik Öğretimsel Müdahalelerin Öğrencilerin Akademik Başarılarına Etkisinin İncelenmesi
}

\author{
Tunahan Filiz $(\mathbb{D} 1$
}

$\ddot{O} z$

Giriş: Matematik öğrenme güçlüğü yaşayan öğrenciler bilişsel anlamda hiç öğrenememekten ziyade yavaş ve farklı öğrenen öğrencilerden oluşmaktadır. Öğrenme güçlüğü yaşayan öğrencilerin bireysel farklılıkları nedeniyle bu öğrencileri desteklemek amacıyla öğretimsel müdahaleler geliştirilmiştir. Bu çalışmanın amacı, matematik öğrenme güçlüğü yaşayan öğrenciler için oluşturulan öğretimsel müdahalelerin öğrencilerin akademik başarılarına etkisini inceleyen farklı türden birincil çalışmaları sentezleyerek, güncel ve ayrıntılı bir analiz çalışması yapmaktır.

Yöntem: Matematik öğrenme güçlüğü yaşayan öğrenciler için oluşturulan öğretimsel müdahalelerin öğrencilerin akademik başarılarına etkisinin incelendiği farklı türden birincil çalışmalar meta analiz yöntemi kullanılarak analiz edilmiştir. Çalışmalara ait etki büyüklük değerleri, heterojenlik testi, yayın yanlılı̆̆ı ve ara değişken analizlerine ilişkin bilgiler, CMA (Comprehensive Meta Analysis) istatistik programı kullanılarak hesaplanmıştır.

Bulgular: Yapılan meta analiz çalışmasıyla matematik öğrenme güçlüğü yaşayan öğrenciler için hazırlanan müdahale programlarının öğrencilerin akademik başarı seviyelerinde geniş bir etkiye sahip olduğu tespit edilmiştir (Hedge $\mathrm{g}=0.764, \% 95 \mathrm{CI}=0.494-1.033$ ). Ayrıca yapılan ara değişken analizlerinde etki büyüklük değerlerinin çalışma değişkenlerinden müdahale türü ve tanılama ölçütlerine göre anlamlı düzeyde farklılaştığı; öğrenme alanına, uygulama süresi ve öğretim düzeyine göre ise bir anlamlılık ifade etmediği belirlenmiştir.

Tartışma: Araştırmaya dâhil edilen çalışmalardan elde edilen genel etki büyüklüğü (0.764), öğretimsel müdahalelerin matematik öğrenme güçlüğü yaşayan öğrencilerin matematik performansı üzerinde genel anlamda olumlu bir etkiye sahip olduğunu göstermektedir. Matematik öğrenme güçlüğü yaşayan öğrencilerin desteklenmesi amacıyla farklı öğretimsel müdahalelerin geliştirildiği görülmektedir. Geliştirilen öğretimsel müdahaleler, öğrencilere matematik öğretim sürecinde destek olmakla beraber matematik öğrenme güçlüğü üzerine farkındalık oluşturmaya devam etmektedir. Sonuç olarak, daha fazla öğretimsel müdahale çalışmasına ihtiyaç olduğu ifade edilebilir.

Anahtar sözcükler: Matematik öğrenme güçlüğü, diskalkuli, öğrenme ortamı, öğretimsel müdahaleler, bilgisayar destekli öğretim.

Atıf için: Filiz, T. (2021). Matematik öğrenme güçlüğü yaşayan öğrencilere yönelik öğretimsel müdahalelerin öğrencilerin akademik başarılarına etkisinin incelenmesi. Ankara Üniversitesi Eğitim Bilimleri Fakültesi Özel Ĕ̈itim Dergisi, 22(4), 1025-1055. https://doi.org/10.21565/ozelegitimdergisi.713496

\footnotetext{
10̈̆ğretim Görevlisi, Bayburt Üniversitesi, tunahanfiliz@gmail.com, https://orcid.org/0000-0002-3149-8783
} 


\section{Giriş}

Okuma, yazma ve aritmetik beceriler hem temel bireysel ihtiyaçların karşılanmasında hem de meslek hayatında birtakım toplumsal görevleri yerine getirirken kullandığımız üç temel beceri olarak karşımıza çıkmaktadır (Olkun, 2015). Bu temel becerilerin birinde ya da birkaçında sorun yaşayan öğrenciler öğrenme güçlüğü kavramıyla nitelendirilmektedir. Nitekim öğrenme güçlüğü, diğer akademik öğrenmelere temel oluşturan, okuma, yazma ve aritmetik gibi akademik becerilerin öğrenilmesini ve kullanılmasını engelleyen nöro-gelişimsel bir bozukluk olarak ifade edilmektedir (American Psychological Association [APA], 2013). Günlük hayatımızda matematiksel becerilerin, kişinin iş ve günlük yaşamını desteklemesi, ileri eğitimine devam edenler için temel matematiksel altyapı oluşturması ve diğer akademik alanlara katkısı göz önüne alındığında, önemli bir yere sahip olduğu ifade edilmektedir (Olkun, 2015). Sayma ve hesaplama becerileri, daha sonra öğrenilecek matematiksel becerilerin kazandırılmasında önkoşul becerilerden olduğu için bu temel becerilerde sorun yaşayan öğrencilerin aritmetik performansı olumsuz etkilenebilir (Olkun, 2015). Ayrıca sayı kavramı ve hesaplama becerilerinde güçlük yaşayan öğrenciler, okula devam, mesleki kariyer ve özgüven anlamında birtakım olumsuzluklarla karşılaşabilirler (Kucian \& von Aster, 2015).

Matematik öğrenme güçlüğü, sayı kavramının kazanılması, aritmetik olguların ezberlenmesi, doğru ve akıcı hesaplamalar yapma ve matematiksel muhakeme sorunlarıyla ortaya çıkan matematiksel bir yetersizlik türü olarak ifade edilmektedir (APA, 2013). Matematik öğrenme güçlüğünün yaygınlığı konusunda kesin veriler bulunmamakla beraber oranlar ülkeden ülkeye farklılık göstermektedir. Matematik öğrenme güçlüğünün nasıl tanımlanacağı (örneklem) ve nasıl teşhis edileceği (ölçme araçları) konularında belirsizlikler yaşanması, bu farklılıkların sebebi olarak gösterilebilir (Olkun, 2015). Ancak farklı ülkelerde, yapılan çalışmalardan hareketle eğitim alan tüm çocukların yaklaşık \%5'ini, özel eğitime uygunluğu belirlenmiş tüm çocukların ise \%47'sini bu grup oluşturmaktadır (Cortiella \& Horowitz, 2014; Öz, 2019). Farklı kaynaklarda bu oran \%3 ile \%14 arasında değişmekle beraber çok daha fazla öğrencinin matematik öğrenme güçlüğü yaşadığı, araştırmacılar tarafından ifade edilmektedir (Bird, 2017). Bununla beraber bu oranların çok yüksek olmasında yanlış tanılamanın da etkisi olabileceği düşünülmektedir (Bender, 2016).

Aritmetik becerilerin önemi ve yetersizlik yaşayan öğrenci oranları göz önüne alındığında, matematik öğrenme güçlüğü yaşayan öğrencilerin desteklenmesi ve bu durumla baş etme becerisi kazanmaları önemli bir olgu olarak karşımıza çıkmaktadır. Matematik öğrenme güçlüğü, müdahale edilmediğinde, öğrenciler tarafından zamanla üstesinden gelinebilecek bir durum değildir (Butterworth vd., 2011; Gerber, 2012). Doğru destek sağlanmadığında, öğrenciler sayılar ve aritmetikle ilgili olumsuz tutumlar geliştirirler, bu olumsuz tutumlar matematik kaygısına ve okul yaşamının geneline yönelmiş bir fobiye dönüşebilir (Krinzinger \& Kaufmann, 2006). $\mathrm{Bu}$ nedenle matematik öğrenme güçlüğü yaşayan öğrencilerin, bireysel farklılıkları ve öğrenme tercihleri gözetilerek, matematiksel bilgi ve becerileri, potansiyelleri doğrultusunda geliştirilmelidir (Olkun, 2015).

Matematik öğrenme güçlüğü yaşayan öğrencilerin, matematik öğrenme ve öğretme sürecinde etkili öğretimsel müdahalelerden yararlanabilmeleri ve akademik olarak desteklenmeleri amaciyla erken dönemde tanılanması hayati bir öneme sahiptir (Geary, 2011; Passolunghi \& Lanfranchi, 2012). Öğrenme güçlüğü erken yaşlarda ortaya çıkmakta ancak bu yetersizlik türü öğrenci okula gidene kadar fark edilmemektedir (Akın \& Özmen, 2019). Erken dönem tanılama sürecinde, öğrencilerde gözlemlenen birtakım belirtiler yol gösterici rol oynayabilirler. Öğrenme güçlüğüne sahip öğrenciler, normal gelişim gösteren akranlarından farklı özelliklere sahip olmakla beraber öğrenme güçlüğü tanısı almış akranlarından da farklılık göstermektedirler (Güzel-Özmen, 2015). Matematik öğrenme güçlüğü yaşayan öğrenciler, sayılar ve matematiksel hesaplamalarda güçlük yaşarlar (Öz, 2019), sorulara geç cevap verirler ve akranlarına göre yavaştırlar, zihinsel hesaplamada güçlük yaşar, matematiksel dili kullanmada yetersiz kalırlar (Cowan \& Powell, 2014; Butterworth, 2005). Ayrica daha önce öğrendiği işlemleri hızlı bir şekilde unuturlar, sıralama ile ilgili güçlük yaşarlar, yer ve uzamsal durumlarla ilgili yetersizlik gösterirler, anlama yerine taklit ve ezbere dayalı işlem yaparlar (Geary, 2017). Ayrıca bu öğrenciler ölçme, zamanı söyleme, para hesabı yapma, sıralama ve zihinsel işlem yapmakta güçlük çekebilirler (Butterworth \& Yeo, 2004; Emerson \& Babtie, 2010; Öz, 2019). Her ne kadar belirtiler yol gösterici rol oynasa da matematik öğrenme güçlüğü yaşayan bireylerin tanılanması ilkokul iki ve üçüncü sınıfta yapılabilmektedir.

Öğrenme güçlüğü yaşayan öğrencilerin tanılanmasına ilişkin literatür incelendiğinde, farklı kaynaklarda farklı modellerin ele alındığ 1 görülmektedir (Akın \& Özmen, 2019; Olkun, 2015; Flanagan \& Alfonso, 2010; Michaelson, 2007). Bu modellerden ilki, öğrenme güçlüğü belirtilerini doğrudan gözlemleyerek tanılamadır. Bu yöntemde, bireyler gözlemlenir ve matematik öğrenme güçlüğü belirtilerine göre hazırlanan kontrol listeleri kullanılarak bireyin güçlük yaşayıp yaşamadığına karar verilmeye çalışılır (Mutlu, 2016). İkinci olarak, birçok 
ülkede uygulanmakta olan, yetenek ve başarı puanları arasındaki farkı temel alan tutarsızlık modeli ön plana çıkmaktadır (Olkun, 2015; Akın \& Özmen, 2019). Bu modelde, bireyin matematik başarı testinden aldığı puanla zekâ puanı, yaşı ve akademik başarısı arasındaki uyuşmazlık esas alınmaktadır (Mutlu, 2016). Üçüncü model olarak, öğrenme güçlüğü yaşayan öğrencilerin erken yaşlarda teşhis edilmesine ve desteklenmesine imkân veren müdahaleye yanıt modeli gelmektedir. Bu yöntem, akademik açıdan yetersiz olan ve öğrenme güçlüğü yaşayan öğrencileri erken dönemde belirleme ve destekleme sistemi olarak ifade edilmektedir (Witzel \& Little, 2016). Müdahaleye yanıt modeli, öğrenme güçlüğü yaşayan ve düşük akademik performans gösteren öğrencilerin, öğrenme çıtılarının yakından izlenerek, gerektiğinde daha yoğun bilimsel temelli müdahale sağlanması ve bu müdahalelerin yapısının öğrenci tepkileri doğrultusunda düzenlenerek tespit edildiği çok aşamalı bir yaklaşım olarak benimsenmiştir (Johnson vd., 2006; Witzel \& Little, 2016). Diğer bir model de ülkemizde öğrenme güçlüğü yaşayan öğrencilerin tanılanmasında kullanılan, psikolojik işlem değerlendirmesi modelidir. Temelini tıbbi değerlendirme yaklaşımından alan bu modelde, öğrenme güçlüğü tanımından hareketle bireylerin görsel algı, motor ve işitsel becerileri değerlendirilmekte, aynı zamanda zekâ testleriyle zekâ düzeyleri de belirlenmektedir (Akın \& Özmen, 2019). Bu modellerler beraber, düşük başarı (Akın \& Özmen, 2019), öğrenme güçlügüünü dışlayıcı ve kapsayıcı koşullar ve bilgisayar tabanlı diskalkuli tarayıcıları (Mutlu, 2016) gibi modeller de üzerinde durulan tanılama modelleri olarak ifade edilmektedir. Son olarak, Mutlu ve Akgün (2017) tarafından geliştirilen, öğretmen değerlendirmesi, diskalkuli ön-değerlendirme testi, diskalkuli tarama aracı, öğrenci tanıma formu ve zekâ testi birer süzgeç olarak kullanılan Çoklu Süzgeç Modeli de matematik öğrenme güçlüğü yaşayan öğrencilerin tanılanmasında kullanılmaktadır.

Mevcut tanılama yöntemlerine rağmen, matematik öğrenme güçlüğü yaşayan öğrencilerin belirlenmesi, çoğunluğun üzerinde anlaşmaya vardığı bir değerlendirme yönteminin bulunmaması (Gifford, 2006; Gifford \& Rockliffe, 2012; Fletcher vd., 2006) nedeniyle oldukça güçtür. Matematik öğrenme güçlüğü yaşayan öğrencilerin bilişsel yapılarının incelenmesine ilişkin çalışmaların yürütülmesinde yaşanan zorluklar, öğrencilerin heterojen bir yapıya sahip olmaları, ayrıca matematiğin derin ve karmaşık bir yapıya sahip olması matematik öğrenme güçlüğü yaşayan öğrencilerin tespit edilmesinde zorluklara neden olabilir (Geary \& Hoard, 2005). Ülkemizde öğrenme güçlüğü yaşayan öğrencilerin belirlenmesi göz önüne alındığında benzer sorunların yaşandığı ifade edilebilir. Ülkemizde öğrenme güçlüğünü tanılama uygulamalarının ve tanımlanan öğrencilerin uygun özel eğitim hizmetlerine erişimlerinin yeterli olmadığg belirtilmektedir (Özmen, 2014). Matematik öğrenme güçlüğü yaşayan öğrenciler herhangi bir zekâ geriliği, duyu ve duygu bozukluğuna sahip değillerdir (Güzel-Özmen, 2015). Dolayısıyla bu öğrencilerin normal bir zekâya sahip olduğu fakat matematik öğrenmekte güçlük yaşadıkları unutulmamalidır.

Matematik öğrenme güçlüğü yaşayan öğrenciler özel eğitim kapsamında genel eğitim sınıflarında tam zamanlı kaynaştırma öğrencisi olarak eğitimlerine devam etmektedirler. Ayrıca bu öğrenciler matematik derslerinde kaynak oda ve destek eğitim sınıf hizmetlerinden de yararlanmaktadır (Girli, 2015). Matematik öğrenme güçlüğü yaşayan öğrencilerle ilgili yapılan araştırmalar incelendiğinde, bu öğrencilerin normal gelişim gösteren akranları gibi aynı yöntemlerle ve aynı hızda olmasa da matematik öğrenebileceği görülmektedir (Geary vd., 2010; Re vd., 2014). Matematik öğrenme güçlüğü yaşayan öğrenciler bilişsel anlamda hiç öğrenememekten ziyade yavaş ve farklı öğrenen öğrencilerden oluşmaktadır. Öğrenme güçlüğü yaşayan öğrencilerin bireysel farklılıkları nedeniyle bu ögrencileri desteklemek amacıyla kullanılan öğretimsel stratejilerin çeşitlilik göstermesi kaçınılmazdır (Akçin, 2019; Kirk vd., 2017). Öğrenme güçlüğü yaşayan öğrencilerin öğrenme-öğretme sürecini destekleyen, etkililiği bilimsel araştırmalarla kanıtlanmış ve yaygın olarak kullanılan öğretimsel stratejiler bulunmaktadır (Akçin, 2019; Kirk vd., 2017). Araştırmalar, açık (explicit) öğretim, strateji öğretimi, doğrudan öğretim, üstbilişsel yaklaşım ve destekleyici öğretim gibi öğretimsel stratejileri destekler niteliktedir (Berkeley vd., 2010; Graham \& Harris, 2009; Maccini vd., 2007; Gersten vd., 2009). Açık öğretim, kısa ve öz bir dil kullanımını, öğrenilecek konuya yönelik çeşitli örnekler vermeyi, düzeltici geribildirimlerin verildiği ve öğrenilecek bilgilerin organizasyonunu gösteren şemaları kullanmayı gerektiren bir stratejidir (Akçin, 2019; Kirk vd., 2017). Strateji öğretimi, hatırlamayı kolaylaştıran özel yaklaşımları, öğrenilen bilgiler arasında bağlantılar kurmayı ve bilgiyi yeni bağlamlara uygulama yeteneğini içermektedir (Akçin, 2019; Kirk vd., 2017; Gersten vd., 2009). Doğrudan öğretim, model olma, rehberli uygulama firsatları sunma, ilerlemeyi ayarlama, hata düzeltme ve ilerlemeyi kaydetme gibi sistematik aşamaları kullanarak beceri öğretimine odaklanmaktadır (Akçin, 2019). Üstbilişsel yaklaşım, çoğu zaman kendini düzenleme stratejileri olarak isimlendirilir ve kendini düzenleme, hedef belirleme, kendi ilerlemesini kaydetme ve kendini pekiştirme gibi stratejileri kapsamaktadır (Akçin, 2019; Kirk vd., 2017). Destekleyici öğretim ise, ipucu içeren içerik, materyal, görevlerin sistematik olarak sıralanması ve öğrenmeyi en iyi hale getirmek için öğretmen ve akran desteği olarak ifade edilmektedir (Akçin, 2019). 

ÖĞRENCILERİN AKADEMIK BAŞARILARINA ETKISIININ İNCELENMESI

İlgili literatür incelendiğinde, öğretimsel müdahalelerin öğrenciler üzerindeki etkililiğinin incelendiği meta analiz çalışmalarının yapıldığ görülmektedir. Bu meta analiz çalışmalarında, geliştirilen öğretimsel müdahalelerin öğrenme güçlüğü (Lee vd., 2020; Ok vd., 2019; Marita \& Hord, 2016), matematik öğrenme güçlüğü (Jitendra vd., 2018; Monei \& Pedro, 2017; Küçükalkan vd., 2019; Stevens vd., 2017) ve her iki güçlük grubunda olan öğrenciler (Jitendra vd., 2018) üzerine etkisinin incelendiği görülmektedir. Yapılan meta analiz çalışmalarında öğretimsel müdahalelerin ilkokul (Monei \& Pedro, 2017; Chodura vd., 2015; Gersten vd., 2009), ortaokul (Jitendra vd., 2018; Lee vd., 2020; Stevens, 2017) ve lise düzeylerinde (Marita \& Hord, 2016) incelendiği ifade edilebilir. Meta analiz çalışmalarında genel öğretimsel müdahalelerin (doğrudan öğretim, sistematik öğretim, bilişsel öğretim) incelendiği çalışmalarla (Chodura vd., 2015; Gersten vd., 2009) beraber tek bir öğretimsel müdahalenin güçlük yaşayan öğrencilerin matematik öğrenmeleri üzerine etkisini inceleyen meta analiz çalışmaları da yer almaktadır (Kiru vd., 2018). Örneğin, Ok ve diğerleri (2019) tarafından yapılan çalışmada öğrenme güçlüğü yaşayan öğrencilere matematik öğretiminde bilgisayar destekli öğretimin etkileri incelenmiştir. Genel olarak sonuçlar bilgisayar destekli öğretimin öğrenme güçlüğü yaşayan öğrencilerin matematik öğretimlerini desteklemek için umut verici olduğunu göstermektedir. Küçükalkan ve diğerleri (2019) tarafindan yapılan diğer bir çalışmada ise, bilgisayar destekli öğretimin, farklı ülkelerde yapılan çalışmaların sonuçlarını meta analiz yöntemiyle değerlendirerek, matematik öğrenme güçlüğü çeken öğrenciler üzerindeki etkisi incelenmiştir. 2007-2018 yılları arasında yapılan, dâhil edilme ölçütlerini karşılayan 33 deneysel çalışma araştırma kapsamına alınmıştır. Sonuç olarak, bilgisayar destekli öğretimin matematik öğrenme güçlüğü yaşayan öğrencilerin matematik öğretimleri üzerinde olumlu bir etkiye sahip olduğu tespit edilmiştir. Baker ve diğerleri (2002) tarafından yapılan çalışmada, matematik öğrenme güçlügü yaşayan öğrenciler üzerine gerçekleştirilen matematik müdahale çalışmalarının sentezlendiği, 1971-1999 yılları arasında yapılan dâhil edilme ölçütlerini karşılayan 15 araştırma çalışma kapsamına alınmıştır. Bu çalışmada müdahale türü olarak, bilgisayar destekli öğretim, akran destekli öğrenme, ebeveyn desteği ve doğrudan öğretim olmak üzere dört müdahale türüne ilişkin etki büyüklükleri hesaplanmıştır.

Meta analiz çalışmalarında farklı öğretimsel müdahalelerin farklı matematik öğrenme alanları üzerine etkileri incelenmiştir. Öğretimsel müdahalelerin etkisinin tespit edildiği meta analiz çalışmalarında, müdahalelerin farklı matematik öğrenme alanları üzerine etkisi incelenmektedir. Bu çalışmalarda problem çözme (Marita \& Hord, 2016), genel aritmetik beceriler (toplama, çıkarma, çarpma, bölme) (Gersten vd., 2009; Jitendra vd., 2018), kesirler (Shin \& Bryant, 2015) ve cebir (Lee vd., 2020; Stevens vd., 2017) öğrenme alanlarının incelendiği görülmektedir. Lee ve diğerleri (2020) tarafindan yapılan çalışmada, öğrenme güçlüğü yaşayan öğrenciler üzerine geliştirilen öğretimsel müdahalelerin cebir öğrenme alanı üzerine etkisi incelenmiştir. Genel olarak, bu çalışmaya dâhil edilen araştırmalarda, müdahalelerin ardından cebirsel kavramlar ve beceriler konusunda öğrenci başarılarının arttığı ifade edilmektedir. Marita ve Hord (2016) tarafından yürütülen bir diğer çalışmada ise, öğrenme güçlüğü yaşayan ortaokul ve lise öğrencilerinin problem çözme becerilerini desteklemek amaciyla geliştirilen müdahalelerin sistematik bir analizi sunulmaktadır. Sonuç olarak, dâhil edilen çalışmalarda problem çözme becerisinin geliştirilmesini desteklemek için, sistematik öğretim, problem temelli öğretim ve görsel temsil öğretim stratejilerinden yararlanıldığı tespit edilmiştir. Dennis ve diğerleri (2016) tarafından yapılan çalışmada, matematik öğrenme güçlüğü yaşayan öğrencilere yönelik müdahale programlarının incelendiği deneysel ve yarı deneysel çalışmalar nicel olarak özetlenmektedir. 25 çalışmanın sentezlendiği bu çalışmada, çalışmaların etki büyüklükleri, katılımcı özellikleri, müdahale parametreleri, matematik müdahale alanları ve öğretim yaklaşımları incelenmektedir. Sonuç olarak, farklı öğretim yaklaşımları ve çeşitli öğretim bileşenleri güçlük yaşayan öğrencilerin matematik performansındaki gelişmelere katkıda bulunmuştur. Kiru ve diğerleri (2018), matematik öğrenme güçlüğü yaşayan veya risk altındaki öğrencilerin matematiksel sonuçlarını hedef alan teknoloji destekli matematik müdahaleleri üzerine yapılan çalışmaları gözden geçirmektedirler. Literatür taramasında 2000 ve 2016 yılları arasında yayınlanan 19 çalışma (9 tek vaka ve 10 grup/yarı deneysel tasarım) çalışmaya dâhil edilmektedir.

Yapılan meta analizle birlikte mevcut çalışmaların aşağıdaki yollarla genişletilmesi amaçlanmaktadır. İlk olarak, bu çalışmayla 2003-2020 yılları arasında yayınlanmış deneysel ve yarı deneysel müdahale çalışmalarının analizi sunulmaktadır. Yakın zamanda yayınlanan bu müdahale çalışmaları, matematik öğrenme güçlüğü yaşayan öğrencilerin ihtiyaçlarını karşılamaya yönelik en son güncel çalışmaları içermektedir. İkinci olarak, öğrenme güçlüğü yaşayan öğrencilerin heterojen bir yapıda olduğu gerçeğini dikkate alarak, müdahale türüyle birlikte öğrencilerin öğretim düzeyi, tanılama yöntemleri, matematik öğrenme alanı ve müdahale süresi gibi değişkenlere ait etki büyüklükleri de hesaplanmıştır. Üçüncü olarak, müdahale türü başlığı altında bilgisayar destekli öğretim, bireyselleştirilmiş öğretim, somut-temsil-soyut öğretim, şema temelli öğretim gibi on iki öğretimsel müdahaleye ilişkin etki büyüklükleri hesaplanmıştır. Dördüncü olarak, öğrencilerin öğretim düzeyleri incelenerek, ilkokul ve ortaokul kademelerinde güçlük yaşayan öğrenciler karşılaştırmalı olarak incelenmiştir. Ayrıca bu çalışmayla 
birlikte öğrenme güçlüğü yaşayan öğrenciler için etkili müdahalelerin temelini oluşturan öğretim bileşenleri önceki çalışmalar yardımıyla belirlenmiştir (Zheng vd., 2013). Bu öğretim bileşenlerinin, özellikle sınıf öğretmenlerine ve diğer öğretmenlere öğrenme güçlüğü yaşayan öğrenciler için oluşturacakları etkili öğretimsel müdahaleler için rehber olması düşünülmektedir. Meta analiz çalışmaları alandaki eğilimi göstermesi ve alanda çalışacak araştırmacılara rehber olması bakımından önemli görülmektedir. Son olarak, ülkemiz literatüründe öğretimsel müdahalelerin matematik öğrenme güçlüğü yaşayan öğrencilerin başarıları üzerindeki etkisini ortaya koyan herhangi bir çalışmaya rastlanılmamıştır. Tüm bunlar göz önüne alındığında araştırmanın amacı, matematik öğrenme güçlüğü yaşayan öğrenciler için oluşturulan etkili öğretimsel müdahalelerin tespit edilmesi, bu müdahalelerin öğrencilerin akademik başarılarına etkisini inceleyen farklı türden birincil çalışmaları sentezleyerek, öğretmenlere ve alanda çalışacak araştırmacılara yol göstermektir.

\section{Yöntem}

Matematik öğrenme güçlüğü yaşayan öğrenciler için oluşturulan müdahale programlarının bu öğrencilerin akademik başarılarına etkisinin incelendiği çalışmada meta analiz yönteminden yararlanılmıştır. Meta analiz yöntemiyle yapılan araştırmalar benzer ya da ilişkili amaca sahip araştırmalardan elde edilen sonuçların nicel olarak birleştirilmesiyle beraber daha genellenebilir ve diğer araştırmalarla doğrulanmış sonuçlara ulaşmamızı sağlayan araştırmalardır (Büyüköztürk vd., 2017; Arthur vd., 2001). Bu nedenle meta analiz çalışması kapsamına alınacak çalışmalar istatistik bulgular içeren çalışmalar olmalıdır (Büyüköztürk vd., 2017). Genel olarak meta analiz çalışmaları, çalışmalara ait etki büyüklük değerleri arasındaki ilişkinin heterojen olup olmadığını test etmek, incelenen ilişkinin etki büyüklüğünün güven aralığını ve istatistiksel anlamlılığını belirlemek ve çalışmalar arasında heterojenlik sonucuna neden olan olası değişkenleri belirlemek amacıyla yapılmaktadır (Huedo-Medina vd., 2006). Bu meta analiz çalışmasında takip edilecek adımlar şu şekildedir:

\section{Araştırmanın Amacı, Problemi ve Bağımlı/Bağımsız Değişkeni}

Meta analiz çalışmasında ilk adım diğer yöntemlerde de olduğu gibi araştırmanın amacının ve problemin ortaya konulmasıdır (Card, 2011). Bu bilgi çerçevesinde bu araştırmanın amacı, matematik öğrenme güçlüğü yaşayan öğrenciler için oluşturulan etkili öğretimsel müdahalelerin tespit edilmesi, bu müdahalelerin öğrencilerin akademik başarılarına etkisini inceleyen farklı türden birincil çalışmaları sentezleyerek, öğretmenlere ve alanda çalışacak araştırmacılara yol göstermektir. Öğrencilerin akademik başarılarını geliştirmek amacıyla oluşturulan müdahale programlarının incelendiği deneysel ve yarı deneysel çalışmalar meta analiz kapsamında incelenmiştir. Oluşturulan müdahale programlarının bağımsız değişken olduğu farklı çalışmalarda matematik öğrenme güçlüğü yaşayan öğrencilerin akademik başarılarını etkileyebileceği düşünülen müdahale türü, tanılama yöntemi, matematik öğrenme alanı, müdahalenin uygulandığı öğretim düzeyi ve uygulama süresi çalışma değişkenleridir. $\mathrm{Bu}$ çalışmada aşağıdaki sorulara cevap aranmaktadır:

1. Matematik öğrenme güçlüğü yaşayan öğrenciler için oluşturulan müdahale programlarının öğrencilerin akademik başarılarına etkisi nedir?

2. Matematik öğretiminde kullanılan müdahale türüne göre çalışmaların etki büyüklükleri arasındaki fark anlamlı midır?

3. Öğrencilerin belirlenmesinde kullanılan tanılama ölçütlerine göre çalışmaların etki büyüklükleri arasındaki fark anlamlı mıdır?

4. Çalışmalara ait etki büyüklük değerleri matematik öğretiminin gerçekleştirildiği öğrenme alanlarına göre anlamlı bir fark oluşturmakta mıdır?

5. Çalışmaların etki büyüklükleri arasında müdahalenin gerçekleştirildiği öğretim düzeyine göre anlamlı bir fark oluşmakta midır?

6. Oluşturulan müdahale programının süresi çalışmaların etki büyüklükleri arasındaki farkı anlamlaştırır $\mathrm{m} 1$ ?

\section{Veri Toplama}

Araştırmanın amacı ve problemi belirlendikten sonra bazı veri tabanları kullanılarak tarama yapılmıştır. $\mathrm{Bu}$ amaçla Academic Search Complete, Educational Resorces Information Center (ERIC), Science Direct, Springer Link, Taylor \& Francis Online, Scopus, ULAKBIM Ulusal Veri tabanları (UVT), Web of Science, Sage Journals, Wiley Online Library Full Collection ve Google Scholar veri tabanlarından yararlanılmıştır. Ayrıca, Exceptional Children, Journal of Individual Differences, Journal of Learning Disabilities, Journal of Special Education, Learning Disabilities Research and Practice, Learning Disability Quarterly, Remedial and Special Education ve The Elementary School Journal dergilerinin el ile taraması gerçekleştirilmiştir. Bilgisayar ve el ile 
arama sonucunda 562 makaleye ulaşılmıştır. Alan yazın taramasında matematik öğrenme güçlüğü (mathematics learning difficulty/disability), diskalkuli (dyscalculia), öğrenme güçlükleri (learning difficulty/disability), öğrenme ortamı (learning environment), öğrenme ortamı tasarımı (learning envirenment design), müdahale veya tedavi (intervention or treatment), matematik eğitimi (mathematics education), matematiksel müdahaleler (mathematical interventions), risk altında (at risk) anahtar kelimelerinden ve bu kelimelerin İngilizce karşılıklarından yararlanılmıştır. Sonuç olarak 76 çalışma tespit edilmiştir.

\section{Dâhil Edilme Ölçütleri}

Meta analiz çalışmasına dâhil edilen çalışmaların niteliği meta analizin sonucunu etkileyen önemli noktalardan birisi olarak görülmektedir. Dolayısıyla meta analize dâhil edilen araştırmaların belirlenmesinde dâhil edilme ölçütleri önemli görülmektedir. Çalışmaların belirlenmesi amacıyla dikkate alınan ölçütler şunlardır:

1. Çalışmaların matematik öğrenme güçlüğü yaşayan öğrencilere yönelik akademik becerilerini ele alan öğretim, müdahale veya iyileştirme sağlamış olması,

2. Çalı̧̧malarda, müdahaleye alınan öğrencilerin okul çağı öğrencileri olmaları ve araştırmacılar tarafindan matematik öğrenme güçlüğü yaşayan öğrencilerin açıkça tanımlanması,

3. Çalışmalarda deneysel grup ya da yarı deneysel grup yöntemlerinin kontrol grubu ile kullanılmış olması,

4. Çalışmada etki büyüklüklerinin hesaplanmasına izin verecek bilgilere yer verilmiş olması,

5. İncelenen çalışmaların hakemli dergilerde yayınlanmış olması ve İngilizce olarak yazılmış olması,

6. Çalışmaların 2003-2020 yılları arasında yayınlanmış olması

Belirlenen ölçütler çerçevesinde hangi çalışmaların bu ölçütleri karşıladığını belirlemek için yapılan incelemede, matematik öğrenme alanlarından herhangi bir öğrenme alanına ait olmayan, meta analiz çalışması için kullanmamız gereken istatistiki bilgilerin olmadığı, meta analize uygun olmayan araştırma yöntemleriyle yapılmış olan araştırmalar çalışmaya dâhil edilmemiştir. Bu inceleme sonucunda 24 çalışma araştırmaya dâhil edilmiştir. Çalışmalara ait tarama, dâhil etme ve dışlama süreçlerine ilişkin bilgiler Şekil 1'de sunulmuştur. 


\section{Şekil 1}

Tarama ve Çalışmaları Dâhil Etme-Dışlama Süreci Uygulama Akışı (The PRISMA Statement)
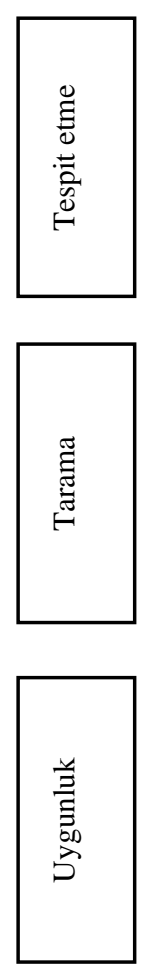

兽
Diğer kaynaklardan tespit edilen ek $\operatorname{kay} 1$ lar $(n=4)$

${ }^{a}$ Bir çalışmada iki deneysel çalışma yer almaktadır, toplamda 24 çalışma yer almaktadır.

\section{Kodlama Süreci ve Geçerlik/Güvenirlik Çalışmaları}

Çalışmalar araştırmacı tarafından hazırlanan form kullanılarak kodlanmıştır. Hazırlanan formun ilk bölümünde çalışmayla ilgili tanımlayıcı bilgiler (adı, yayın türü, yazar/yazarlar, çalışmanın yapıldığı yer, örneklem büyüklügü̆, araştırma yürütücüsü ve yapılma zamanı) yer almaktadır. İkinci bölümde çalışmayla ilgili açıklayıcı bilgilere (tanılama ölçütü, müdahale türü, öğretim düzeyi, müdahale süresi ve öğrenme alanı) yer verilmiştir. Son bölümde ise etki büyüklüğü hesaplamalarında gerekli görülen kontrol ve deney grubuna ait nicel verilere (örneklem büyüklüğü, ortalama, standart sapma) yer verilmektedir. Yapılan kodlamalar sonucunda çeşitli değişkenler içeren aşağıdaki kategorilere dayalı kodlamalar geliştirilmiştir:

1. Müdahale türü: $\mathrm{Bu}$ kategoride yer alan değişkenler, araştırmalarda ele alınan öğretimsel strateji ve düzenlemelerden oluşmaktadır. Değişkenler araştırmalarda isimlendirildiği şekliyle ele alınmıştır.

2. Tanılama yöntemi: Bu kategoride ele alınan değişkenler, matematik öğrenme güçlüğü yaşayan ve risk altında olan öğrencilerin belirlenmesinde kullanılan tanılama yöntemlerinden oluşmaktadır. Araştırmaya dâhil edilen katılımcı grubun belirlenmesinde kullanılan yöntemler (test, ölçek, gözlem) ele alınmıştır.

3. Öğrenme alanı: Matematik öğrenme güçlüğü yaşayan öğrenciler için hazırlanan müdahale programlarında kullanılan matematik öğrenme alanlarının isimleri kodlanmıştır. Öğrenme alanına ilişkin değişkenler, sayı algısı, kesirler, geometri-ölçme, cebir ve problem çözme öğrenme alanlarından oluşmaktadır (Witzel \& Little, 2016). 
4. Öğretim düzeyi: İncelenen çalı̧̧malar ilkokul ve ortaokula yönelik çalışmalar olarak iki değişkende kodlanmaktadır.

5. Müdahale süresi: Kısa süreli 1-7 oturum, orta süreli $8-28$ oturum ve uzun süreli 28 oturumdan fazla (Xin \& Jitendra, 1999) değişkenlerinden oluşmaktadır.

Kodlama formuna ilişkin geçerlik çalışmaları için biri Özel Eğitim bölümünde, diğeri ise Matematik Eğitimi bölümünde öğretim üyesi iki uzmandan formu; açıklık, anlaşılırlık ve incelenecek konuyu kapsama bakımından değerlendirilmesi istenmiştir. Uzman görüşü formu 5'li likert tipte, kesinlikle uygun (5), uygun (4), kararsızım (3), uygun değil (2) ve kesinlikle uygun değil (1) şeklinde hazırlanmıştır. Bu bilgiler doğrultusunda kodlama formuna son şekli verilmiştir. Kodlamalar elektronik ortamda oluşturulan forma işlenmiştir. Kodlama ișlemlerinde eleștirel değerlendirmelere izin veren şeffaflık ve birincil çalıșmaların doğruluğunu ortaya koyan tekrarlanabilirlik önemli iki konu olarak karşımıza çıkmaktadır (Wilson, 2009).

Meta analiz çalışmalarında önemli bir diğer konu ise güvenirliğin sağlanmasıdır. Kodlama güvenirliği iki boyuttan oluşmaktadır. İlki, bir kodlayıcının çalışmadan çalışmaya kodlama tutarılığını ifade eden kodlayıcı güvenirliğidir. İkincisi ise, farklı kodlayıcılar arasındaki tutarlılığı ifade eden kodlayıcılar arası güvenirliktir (Lipsey \& Wilson, 2001). Bu doğrultuda, kodlayıcılar arası güvenirliğin sağlanması amacıyla çalışma en az iki kişi tarafından değerlendirmeye tabi tutulmaktadır. Çalışma sayısının sınırlı olduğu küçük ölçekli meta analiz çalışmalarında genelde ikili kodlama yapılmaktadır. Çalışma sayısının fazla olduğu büyük ölçekli meta analiz çalışmalarında ise seçkisiz örnekleme yöntemi kullanılmaktadır (Wilson, 2009). Bu araştırma küçük ölçekli meta analiz çalışması olduğu için ikili kodlama tercih edilmiştir.

Bu çalışmada kodlama güvenirliğini sağlamak için farklı yöntemler kullanılmıştır. İlk olarak, çalışmalar uzman görüşüne başvurularak kodlanmıştır. İkinci olarak, bağımsız kodlayıcılar arasındaki güvenirlik hesaplanmışıı. Daha sonra uzlaşma oranı kullanılarak, bağımsız kodlama yapan iki kodlayıcı arasındaki uyum hesaplanmıştır. Uzlaşma oranı, kodlayıcılar arası güvenirliğin ölçülmesinde kullanılabilir (Orwin \& Vevea, 2009). $\mathrm{Bu}$ oran, üzerinde anlaşılan görüş sayısının toplam görüşe oranlanmasıyla elde edilmektedir. Bu araştırma için kodlayıcılar arası güvenirlik değeri en az 0.90 en fazla 0.98 olmak üzere ortalama 0.94 olarak hesaplanmıştır. Çalışmalara ilişkin betimsel veriler Tablo 1'de sunulmuştur.

Tablo 1

Çalışmalara İlişkin Betimsel Veriler

\begin{tabular}{|c|c|c|c|c|c|c|}
\hline Araştırma & $\begin{array}{l}\text { Öğretim } \\
\text { düzeyi }\end{array}$ & $\begin{array}{l}\text { Deneysel işlem } \\
\text { süresi }\end{array}$ & Müdahale türü & Tanılama yöntemi & $\begin{array}{c}\text { Öğrenme } \\
\text { alanı }\end{array}$ & $\begin{array}{c}\text { Hedges's g } \\
{[95 \% \mathrm{CI}]}\end{array}$ \\
\hline $\begin{array}{l}\text { Kaufmann ve } \\
\text { diğerleri } \\
(2003)\end{array}$ & 3. sinif & $\begin{array}{l}72 \text { oturum ( } 6 \text { ay } \\
\text { boyunca haftada } \\
3 \mathrm{kez} 25 \text { er dk.) }\end{array}$ & $\begin{array}{l}\text { Bireyselleştirilmiş } \\
\text { eğitim (Küçük grup } \\
\text { oturumlarında) }\end{array}$ & $\begin{array}{l}\text { Matematik başarı testi (Sayı } \\
\text { işleme ve hesaplama } \\
\text { tarama bataryası) }\end{array}$ & Sayı bilgisi & $\begin{array}{c}0.618 \\
{[-0.291} \\
1.528]\end{array}$ \\
\hline $\begin{array}{l}\text { Graham ve } \\
\text { diğerleri } \\
(2007)\end{array}$ & 5-7. sinif & $\begin{array}{l}78 \text { oturum }(26 \\
\text { hafta boyunca } \\
\text { haftada } 3 \text { defa } \\
\text { 30'ar dk.) }\end{array}$ & $\begin{array}{l}\text { QuickSmart matematik } \\
\text { müdahalesi }\end{array}$ & $\begin{array}{l}\text { Bilişsel Yetenek } \\
\text { Değerlendirme Sistemi } \\
\text { (CAAS) (sayılar, toplama, } \\
\text { çıkarma, bölme ve çarpma) }\end{array}$ & Sayı bilgisi & $\begin{array}{r}1.078 \\
{[0.368} \\
1.788]\end{array}$ \\
\hline $\begin{array}{l}\text { Fuchs ve } \\
\text { diğerleri } \\
(2008)\end{array}$ & 3. sinif & $\begin{array}{l}16 \text { oturum (16 } \\
\text { hafta) }\end{array}$ & Şema destekli öğretim & $\begin{array}{l}\text { Akıcılık hesaplama } \\
\text { testi/Wechsler Kısaltılmış } \\
\text { Zekâ Ölçeği/Woodcock - } \\
\text { Johnson III başarı testi }\end{array}$ & $\begin{array}{l}\text { Problem } \\
\text { çözme }\end{array}$ & $\begin{array}{r}1.125 \\
{[0.994} \\
1.256]\end{array}$ \\
\hline $\begin{array}{l}\text { Bellert } \\
(2009)\end{array}$ & 5-7. sinif & $\begin{array}{l}66 \text { oturum ( } 22 \\
\text { hafta boyunca } \\
\text { haftada } 3 \text { defa } \\
\text { 30'ar dk.) }\end{array}$ & $\begin{array}{l}\text { QuickSmart matematik } \\
\text { müdahalesi (kanıta } \\
\text { dayalı stratejiler ve } \\
\text { öğretim yaklaşımları) }\end{array}$ & $\begin{array}{l}\text { Bilişsel Yetenek } \\
\text { Değerlendirme Sistemi } \\
\text { (CAAS) (sayılar, toplama, } \\
\text { ç1karma, bölme ve çarpma) }\end{array}$ & Sayı bilgisi & $\begin{array}{c}0.520 \\
{[-0.352} \\
1.392]\end{array}$ \\
\hline $\begin{array}{l}\text { Bottge ve } \\
\text { diğerleri } \\
(2010)\end{array}$ & 6-8. sinif & $\begin{array}{l}24 \text { oturum ( } 24 \text { gün } \\
\text { boyunca her gün } \\
50 \text { 'şer } \mathrm{dk} .)\end{array}$ & $\begin{array}{l}\text { Geliştirilmiş bağlantılı } \\
\text { müdahale (bilgisayar } \\
\text { tabanlı, video tabanlı } \\
\text { ve uygulamalı } \\
\text { etkinlikler) }\end{array}$ & $\begin{array}{l}\text { Iowa temel beceri testi } \\
\text { (ITBS) }\end{array}$ & Kesirler & $\begin{array}{r}1.059 \\
{[0.495} \\
1.622]\end{array}$ \\
\hline $\begin{array}{l}\text { Bryant ve } \\
\text { diğerleri } \\
(2011)\end{array}$ & 1. sinif & $\begin{array}{l}23 \text { oturum ( } 23 \\
\text { hafta boyunca } \\
\text { haftada } 4 \text { gün } \\
20 \text { 'şer dk.) }\end{array}$ & $\begin{array}{l}\text { Tier } 2 \text { Müdahale } \\
\text { programı }\end{array}$ & $\begin{array}{l}\text { Texas Erken Matematik } \\
\text { Envanterleri - İlerleme } \\
\text { İzleme (TEMI-PM) }\end{array}$ & Sayı bilgisi & $\begin{array}{c}0.148 \\
{[-0.147} \\
0.444]\end{array}$ \\
\hline
\end{tabular}


Tablo 1 (devamı)

\begin{tabular}{|c|c|c|c|c|c|c|}
\hline Araştırma & $\begin{array}{c}\text { Öğretim } \\
\text { düzeyi }\end{array}$ & $\begin{array}{c}\text { Deneysel işlem } \\
\text { süresi }\end{array}$ & Müdahale türü & Tanılama yöntemi & Öğrenme alanı & $\begin{array}{c}\text { Hedges's g } \\
{[95 \% \mathrm{CI}]}\end{array}$ \\
\hline $\begin{array}{l}\text { Miller \& } \\
\text { Kaffar } \\
(2011)\end{array}$ & 2. $\sin 1 f$ & $\begin{array}{l}16 \text { oturum (6 hafta } \\
\text { boyunca } 16 \text { ders } \\
20 \text { 'şer dk.) }\end{array}$ & $\begin{array}{l}\text { Somut-temsil-soyut } \\
\text { öğretim (CRA) }\end{array}$ & $\begin{array}{l}\text { Müfredat temelli } \\
\text { değerlendirme }\end{array}$ & $\begin{array}{l}\text { Geometri- } \\
\text { ölçme }\end{array}$ & $\begin{array}{c}0.996 \\
{[0.163} \\
1.828]\end{array}$ \\
\hline $\begin{array}{l}\text { Burns ve } \\
\text { diğerleri } \\
(2012)\end{array}$ & $\begin{array}{l}3 \text { ve } 4 . \\
\text { sinif }\end{array}$ & $\begin{array}{l}\text { 24-45 oturum ( } 8-15 \\
\text { hafta boyunca } \\
\text { haftada } 3 \text { gün } 15 \text { 'er } \\
\text { dk.) }\end{array}$ & $\begin{array}{l}\text { Bilgisayar destekli } \\
\text { öğretim }\end{array}$ & $\begin{array}{l}\text { Matematik başarı testi } \\
\text { (STAR Math) }\end{array}$ & Sayı bilgisi & $\begin{array}{r}0.358 \\
{[0.123} \\
0.593]\end{array}$ \\
\hline $\begin{array}{l}\text { Burns ve } \\
\text { diğerleri } \\
(2012)\end{array}$ & $\begin{array}{l}3 \text { ve } 4 . \\
\text { sinif }\end{array}$ & $\begin{array}{l}\text { 24-45 oturum ( } 8-15 \\
\text { hafta boyunca } \\
\text { haftada } 3 \text { gün } 15 \text { 'er } \\
\text { dk.) }\end{array}$ & $\begin{array}{l}\text { Bilgisayar destekli } \\
\text { öğretim }\end{array}$ & $\begin{array}{l}\text { Matematik başarı testi } \\
\text { (STAR Math) }\end{array}$ & Sayı bilgisi & $\begin{array}{r}0.487 \\
{[0.175} \\
0.800]\end{array}$ \\
\hline $\begin{array}{l}\text { Huang ve } \\
\text { diğerleri } \\
(2012)\end{array}$ & $\begin{array}{l}2 . \text { ve } 3 . \\
\text { sinif }\end{array}$ & Belirtilmemiş & $\begin{array}{l}\text { Bilgisayar destekli } \\
\text { matematik problem } \\
\text { çözme sistemi }\end{array}$ & $\begin{array}{l}\text { Matematik başarı testi ve } \\
\text { veli izni }\end{array}$ & $\begin{array}{l}\text { Problem } \\
\text { çözme }\end{array}$ & $\begin{array}{c}0.151 \\
{[-0.586} \\
0.888]\end{array}$ \\
\hline $\begin{array}{l}\text { Fuschs ve } \\
\text { diğerleri } \\
(2013 a)\end{array}$ & 1. Sinif & $\begin{array}{l}48 \text { oturum (16 hafta } \\
\text { boyunca haftada } 3 \\
\text { defa } 30 \text { 'ar dk.) }\end{array}$ & $\begin{array}{l}\text { Bireyselleştirilmiş } \\
\text { eğitim (birebir özel } \\
\text { ders) }\end{array}$ & $\begin{array}{l}\text { Geniş Kapsamlı Başarı } \\
\text { Testi-3 (WRAT-3) ve } \\
\text { Wechsler Kısaltılmış } \\
\text { Zekâ Ölçeği (WASI-IQ) }\end{array}$ & Sayı bilgisi & $\begin{array}{c}0.955 \\
{[0.766} \\
1.145]\end{array}$ \\
\hline $\begin{array}{l}\text { Fuschs ve } \\
\text { diğerleri } \\
(2013 b)\end{array}$ & 4. $\sin 1 f$ & $\begin{array}{l}36 \text { oturum ( } 12 \text { hafta } \\
\text { boyunca haftada } 3 \\
\text { defa } 30 \text { 'ar dk.) }\end{array}$ & $\begin{array}{l}\text { Kesir müdahale } \\
\text { programı (senaryolar } \\
\text { yardımıyla küçük } \\
\text { grup eğitimi) }\end{array}$ & $\begin{array}{l}\text { Geniş Kapsamlı Başarı } \\
\text { Testi-4 (WRAT-4) ve } \\
\text { Wechsler Kısaltılmış } \\
\text { Zekâ Ölçeği (WASI-IQ) }\end{array}$ & Kesirler & $\begin{array}{c}0.932 \\
{[0.676} \\
1.188]\end{array}$ \\
\hline $\begin{array}{l}\text { Jitendra ve } \\
\text { diğerleri } \\
(2013)\end{array}$ & 3. $\sin 1 f$ & $\begin{array}{l}30 \text { oturum ( } 6 \text { hafta } \\
\text { boyunca haftada } 5 \\
\text { defa) }\end{array}$ & Şema Tabanlı Öğretim & $\begin{array}{l}\text { Grup Matematik Ölçme ve } \\
\text { Tanılama Değerlendirme } \\
\text { Süreci ve Uygulamaları } \\
\text { alt testi (GMADE) }\end{array}$ & $\begin{array}{l}\text { Problem } \\
\text { çözme }\end{array}$ & $\begin{array}{r}0.513 \\
{[0.134} \\
0.893]\end{array}$ \\
\hline $\begin{array}{l}\text { Swanson } \\
\text { ve } \\
\text { diğerleri } \\
(2013)\end{array}$ & 3. $\sin 1 f$ & $\begin{array}{l}24 \text { oturum ( } 8 \text { hafta } \\
\text { boyunca haftada } 3 \\
\text { defa } 30 \text { 'ar dk.) }\end{array}$ & $\begin{array}{l}\text { Bilişsel strateji } \\
\text { müdahaleleri (genel } \\
\text { sezgisel, görsel- } \\
\text { şematik) }\end{array}$ & $\begin{array}{l}\text { Matematik Yetenek Testi } \\
\text { (TOMA) ve KeyMath } \\
\text { değerlendirmesi }\end{array}$ & $\begin{array}{l}\text { Geometri- } \\
\text { ölçme }\end{array}$ & $\begin{array}{c}0.673 \\
{[0.025} \\
1.322]\end{array}$ \\
\hline $\begin{array}{l}\text { Faramarzi } \\
\text { \& Sadri } \\
(2014)\end{array}$ & 2. $\sin 1 f$ & $\begin{array}{l}10 \text { oturum ( } 2 \text { ay } \\
\text { boyunca } 2 \text { saatlik } \\
10 \text { seans })\end{array}$ & $\begin{array}{l}\text { Nöropsikolojik } \\
\text { müdahale }\end{array}$ & $\begin{array}{l}\text { Key Math değerlendirmesi } \\
\text { ve Wechsler Zekâ Ölçeği } \\
\text { (WISC-III-R) }\end{array}$ & Sayı bilgisi & $\begin{array}{r}4.843 \\
{[3.433} \\
6.252]\end{array}$ \\
\hline $\begin{array}{l}\text { Kanive ve } \\
\text { diğerleri } \\
(2014)\end{array}$ & $\begin{array}{l}4 \text { ve } 5 . \\
\text { sinif }\end{array}$ & $\begin{array}{l}6 \text { oturum (6 seans } \\
15 \text { 'er dk.) }\end{array}$ & $\begin{array}{l}\text { Bilgisayar Destekli } \\
\text { Öğretim }\end{array}$ & $\begin{array}{l}\text { Akademik İlerleme Ölçme } \\
\text { Matematik Alt Testi }\end{array}$ & $\begin{array}{l}\text { Problem } \\
\text { çözme }\end{array}$ & $\begin{array}{r}0.590 \\
{[0.962} \\
1.118]\end{array}$ \\
\hline $\begin{array}{l}\text { Re ve } \\
\text { diğerleri } \\
(2014)\end{array}$ & $\begin{array}{l}\text { 2, } 3,4 \text { ve } \\
\text { 5. sinif }\end{array}$ & $\begin{array}{l}32 \text { oturum ( } 4 \text { ay } \\
\text { boyunca haftada iki } \\
\text { defa } 75 \text { 'er dk.) }\end{array}$ & $\begin{array}{l}\text { Bireyselleştirilmiş } \\
\text { eğitim }\end{array}$ & $\begin{array}{l}\text { Wechsler Zekâ Ölçeği } \\
\text { (WISC III) }\end{array}$ & Sayı bilgisi & $\begin{array}{r}0.966 \\
{[0.052} \\
1.879]\end{array}$ \\
\hline $\begin{array}{l}\text { Bottge ve } \\
\text { diğerleri } \\
(2015)\end{array}$ & 6-8. sinif & $\begin{array}{l}66 \text { oturum } \\
\text { (66 gün boyunca } \\
45^{\prime} \text { er dk.) }\end{array}$ & $\begin{array}{l}\text { Geliştirilmiş bağlantılı } \\
\text { müdahale (bilgisayar } \\
\text { destekli, video } \\
\text { destekli ve } \\
\text { uygulamalı } \\
\text { etkinlikler) }\end{array}$ & $\begin{array}{l}\text { Iowa temel beceri testi } \\
\text { (ITBS) }\end{array}$ & Kesirler & $\begin{array}{r}0.645 \\
{[0.298} \\
0.991]\end{array}$ \\
\hline $\begin{array}{l}\text { Mohd } \\
\text { Syah ve } \\
\text { diğerleri } \\
(2015)\end{array}$ & 1. Sinif & $\begin{array}{l}5 \text { oturum ( } 5 \text { gün } \\
\text { boyunca günde bir } \\
\text { saat) }\end{array}$ & $\begin{array}{l}\text { Bilgisayar destekli } \\
\text { oyun müdahalesi } \\
\text { (Math. Ace) }\end{array}$ & $\begin{array}{l}\text { Gözlem ve matematik } \\
\text { başarı testi ( } 35 . \text { yüzdelik } \\
\text { dilimin altında başarı } \\
\text { gösterenler) }\end{array}$ & Sayı bilgisi & $\begin{array}{r}1.547 \\
{[0.923} \\
2.172]\end{array}$ \\
\hline $\begin{array}{l}\text { Fien ve } \\
\text { diğerleri } \\
(2016)\end{array}$ & 1. sinif & $\begin{array}{l}48 \text { oturum (12 hafta } \\
\text { boyunca haftada } 4 \\
\text { defa } 15 \text { 'er dk.) }\end{array}$ & $\begin{array}{l}\text { Bilgisayar destekli } \\
\text { oyun müdahalesi } \\
\text { (NumberShire Level } \\
1 \text { [NS1]) }\end{array}$ & $\begin{array}{l}\text { easyCBM-CCSS (Ortak } \\
\text { Çekirdek Eyalet } \\
\text { Standartları) }\end{array}$ & Cebir & $\begin{array}{c}0.245 \\
{[-0.003} \\
0.493]\end{array}$ \\
\hline
\end{tabular}


Tablo 1 (devamı)

\begin{tabular}{|c|c|c|c|c|c|c|}
\hline Araştırma & $\begin{array}{l}\text { Öğretim } \\
\text { düzeyi }\end{array}$ & $\begin{array}{l}\text { Deneysel işlem } \\
\text { süresi }\end{array}$ & Müdahale türü & Tanılama yöntemi & $\begin{array}{c}\text { Öğrenme } \\
\text { alanı }\end{array}$ & $\begin{array}{c}\text { Hedges's g } \\
{[95 \% \mathrm{CI}]}\end{array}$ \\
\hline $\begin{array}{l}\text { Flores ve } \\
\text { diğerleri } \\
(2018)\end{array}$ & 5. Sinıf & $\begin{array}{l}20 \text { oturum ( } 5 \text { hafta } \\
\text { boyunca, haftada } \\
4 \text { gün) }\end{array}$ & $\begin{array}{l}\text { Somut-temsil-soyut } \\
\text { öğretim (CRA) }\end{array}$ & $\begin{array}{l}\text { KeyMath } 3 \text { Tanı } \\
\text { Değerlendirmesi: Sayı } \\
\text { ve işlemler }\end{array}$ & Kesirler & $\begin{array}{c}1.035 \\
{[0.299} \\
1.770]\end{array}$ \\
\hline $\begin{array}{l}\text { Hellstrand ve } \\
\text { diğerleri } \\
(2019)\end{array}$ & 1. Sinif & $\begin{array}{l}16 \text { oturum (4 } \\
\text { hafta boyunca } \\
\text { haftada 4'er } \\
\text { defa) }\end{array}$ & $\begin{array}{l}\text { Bilgisayar destekli oyun } \\
\text { müdahalesi } \\
\text { (Number Race) }\end{array}$ & $\begin{array}{l}\text { Matematik başarı testi } \\
\text { (Sayı bilgisi ve aritmetik } \\
\text { işlemler) }\end{array}$ & Sayı bilgisi & $\begin{array}{c}0.299 \\
{[-0.220} \\
0.819]\end{array}$ \\
\hline $\begin{array}{l}\text { Powell ve } \\
\text { diğerleri } \\
(2019)\end{array}$ & 3. Sinif & $\begin{array}{l}16 \text { hafta boyunca } \\
45 \text { oturum }\end{array}$ & $\begin{array}{l}\text { Kelime problem } \\
\text { müdahalesi }\end{array}$ & $\begin{array}{l}\text { Tek basamaklı kelime } \\
\text { problemleri testi }\end{array}$ & $\begin{array}{c}\text { Problem } \\
\text { çözme }\end{array}$ & $\begin{array}{c}0.110 \\
{[-0.298} \\
0.517]\end{array}$ \\
\hline $\begin{array}{l}\text { Wang ve } \\
\text { diğerleri } \\
(2019)\end{array}$ & 3. $\sin 1 f$ & $\begin{array}{l}39 \text { oturum (13 } \\
\text { hafta boyunca } \\
\text { haftada } 3 \text { kez } \\
\text { 35'er dk.) }\end{array}$ & $\begin{array}{l}\text { Öz düzenleme öğretimi } \\
\text { (Self regulation-SR) }\end{array}$ & $\begin{array}{l}\text { Geniş Kapsamlı Başarı } \\
\text { Testi-4 (WRAT-4) ve } \\
\text { Wechsler Kısaltılmış } \\
\text { Zekâ Ölçeği (WASI-IQ) }\end{array}$ & Kesirler & $\begin{array}{c}0.982 \\
{[0.380} \\
1.585]\end{array}$ \\
\hline
\end{tabular}

Not: CAAS = Cognitive Aptitude Assesment System; TEMI-PM = Texas Early Mathematics Inventories-Progress Monitoring; WRAT = Wide Range Achievement Test; WASI-IQ = Wechsler Abbreviated Intelligence Scale; GMADE = Group Mathematics Assessment and Diagnostic Evaluation; TOMA = Test of Math Ability; CCSS = Common Core State Standards; ITBS = Iowa Tests of Basic Skills; CRA = Concreterepresentational-abstract.

Meta analize dahil edilen çalışmaların, değişkenlere dağılımını göstermek için frekans ve yüzde değerleri hesaplanmıştır. Bu anlamda çalışmalar, yayım yılı, müdahale türü, öğrenme alanı, öğretim düzeyi oturum süresi, katılımcılar ve uygulamacı değişkenlerine göre incelenmiştir. Hesaplanan frekans ve yüzde değerleri Tablo 2'de verilmiştir.

Tablo 2

Çalışmalara İlişkin Frekans ve Yüzde Değerleri

\begin{tabular}{llcc}
\hline Çalışma değişkenleri & & S1klık $(f)$ & Yüzde $(\%)$ \\
\hline \multirow{3}{*}{ Yayım yılı } & 2003-2010 & 5 & 20.83 \\
& $2010-2015$ & 14 & 58.33 \\
& $2015-2020$ & 5 & 20.83 \\
& Bireyselleştirilmiş öğretim & 3 & 12.5 \\
& Şema tabanlı öğretim & 2 & 8.33 \\
& Somut-temsil-soyut öğretim & 2 & 8.33 \\
& Bilgisayar destekli öğretim & 7 & 29.16 \\
Müdahale türü & Nöropsikolojik müdahale & 4.16 \\
& QuickSmart matematik müdahalesi & 1 & 8.33 \\
& Geliştirilmiş bağlantılı müdahale & 2 & 8.33 \\
& Tier 2 müdahale programı & 2 & 4.16 \\
& Kesir müdahale programı & 1 & 4.16 \\
& Bilişsel strateji müdahalesi & 1 & 4.16 \\
& Kelime problem müdahalesi & 1 & 4.16 \\
& Öz düzenleme öğretimi & 1 & 4.16 \\
& Sayı bilgisi & 1 & 45.83 \\
Öğretim düzeyi & Problem çözme & 11 & 20.83 \\
& Kesirler & 5 & 20.83
\end{tabular}


Tablo 2 (devamı)

\begin{tabular}{llcc}
\hline \multicolumn{1}{c}{ Çalışma değişkenleri } & & S1klık $(f)$ & Yüzde $(\%)$ \\
\hline \multirow{3}{*}{ Oturum süresi } & Kisa süreli (1-7 oturum) & 3 & 12.5 \\
& Orta süreli (8-28 oturum) & 11 & 45.83 \\
& Uzun süreli (28+ oturum) & 10 & 41.66 \\
Katılımcılar & Öğrenme güçlüğü & 1 & 4.16 \\
& Matematik öğrenme güçlüğü & 17 & 70.83 \\
& Risk grubu & 6 & 25 \\
Uygulamacı & Araştırmacı & 8 & 33.33 \\
& Öğretmen & 15 & 62.5 \\
\hline
\end{tabular}

\section{Veri Analizi ve Etki Büyüklük Değerlerinin Hesaplanması}

Meta analiz çalışmalarında, değişkenler arasındaki ilişkiyi yansıtan etki büyüklük değeri temel birim olarak kabul görmektedir (Borenstein vd., 2013). Bu çalışmada veri analizi yapmak amacıyla meta analiz yöntemi kullanılmıştır. Dâhil edilme ölçütlerine göre belirlenen çalışmaların her birinin etki büyüklük değerleri hesaplanmıştır. Meta analiz kapsamında incelenen çalışmaların (\%95) etki büyüklük değerleri, kontrol ve deney grubu sayıları, ortalama ve standart sapma değerleri kullanılarak hesaplanmıştır. Sadece bir çalışmada (\%5) örneklem büyüklüğüyle beraber p değeri kullanılarak etki büyüklüğü hesaplanmıştır. Bu çalışmada, söz konusu çalışmaların etki büyüklüklerinin hesaplanmasında "Hedge $g$ ” etki büyüklük değeri kullanılmıştır. Çalışmalara ait etki büyüklük değerlerinin hesaplanmasında CMA (Comprehensive Meta Analysis) istatistik programı kullanılmıştır. Çalışmalarda birden fazla etki büyüklük değeri olduğunda ortalama etki büyüklük değeri alınmıştır. Ayrıca birden fazla deney grubunun olduğu çalışmalarda, her bir deney grubu için ayrı ayrı etki büyüklük değerleri hesaplanmıştır. Aynı zamanda yayın yanlılığına ait bilgilere ulaşmak amaciyla Huni grafiğiyle beraber "Rosenthal'in Güvenli $N$ Testi”nden yararlanılmıştır. Bunlarla beraber etki büyüklük değerlerindeki anlamlılığın ortadan kalkması için kaç çalışmaya ihtiyaç olduğunun hesaplanması amacıyla "Orwin'in Güvenli N Yöntemi” kullanılmıştır.

\section{Geçerlilik ve Yayın Yanlılığına İlişkin Veriler}

Meta analiz çalışmalarında yayın yanlılığı büyük sorun oluşturmakla beraber geçerliliğin önündeki en büyük tehdit olarak ifade edilmektedir (Copas \& Shi, 2000; Sutton, 2009). Çalışmaların güçlügünü ortaya koymak amacıyla Huni grafiğiyle beraber Rosenthal ve Orwin'in Güvenli $N$ Testi yöntemleri kullanılabilir. Yayın yanlılığını incelemek amacıyla yanlılığı tespit etmekte en iyi yöntemlerden biri olarak kabul edilen huni grafiğinden yararlanılmıştır. Huni grafiği meta analize dâhil edilen çalışmalarla ilgili görsel bilgiler elde etmek amacıyla kullanılmaktadır (Sterne \& Egger, 2005). Ayrıca huni grafiği, etki büyüklükleri ve çalışma büyüklüklerini karşılaştıran bir grafik olarak ifade edilmektedir (Sutton, 2009). Şekil 2'de yanlılıkla ilgili bilgilerin sunulduğu huni grafiği verilmektedir. 


\section{Şekil 2}

Çalışma Yanlılı̆̆ına İlişkin Huni Grafiği

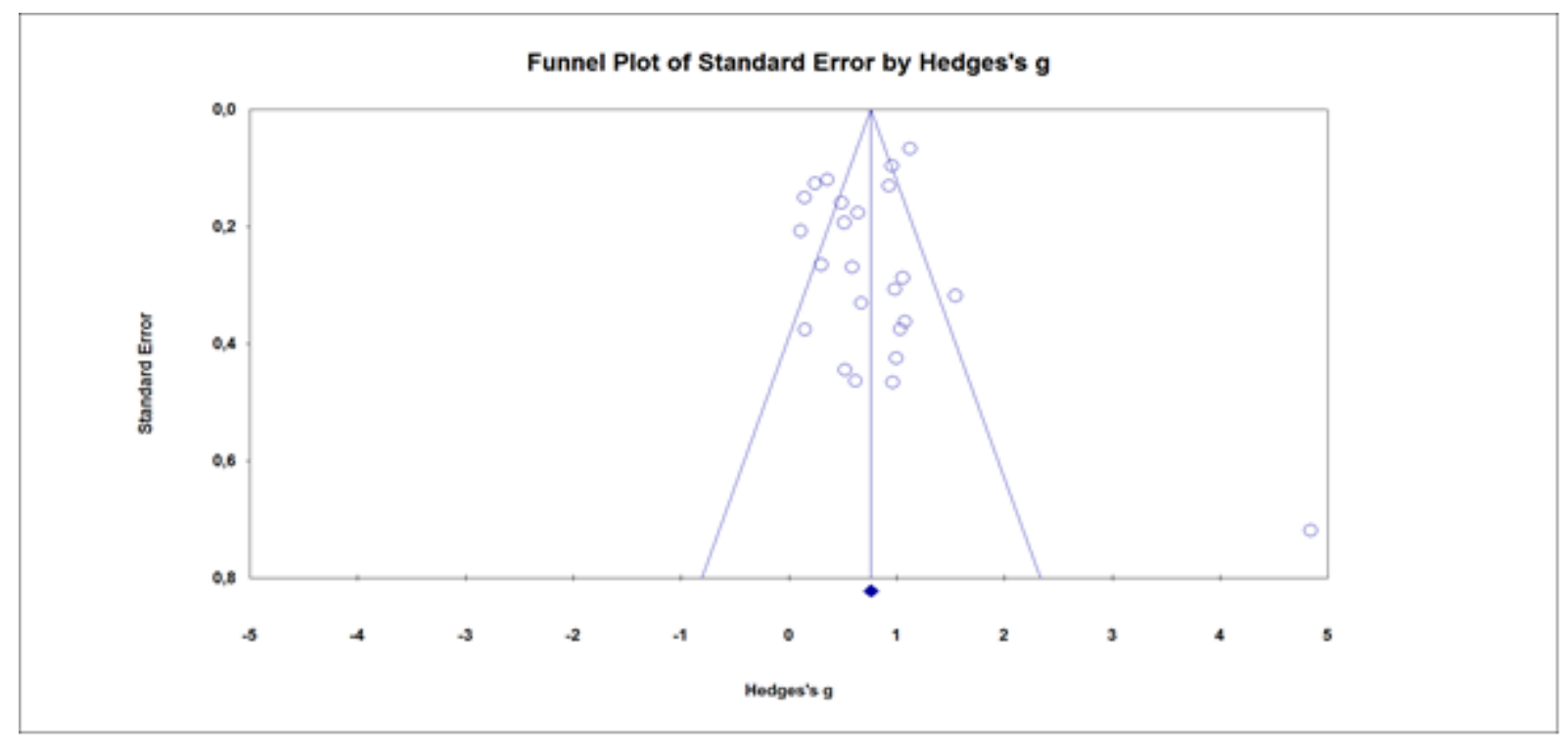

Huni grafiği incelendiğinde çalışmalara ait "Hedge g" etki büyüklük değerlerinin şekilde görüldüğü üzere simetrik bir dağılım gösterdiği söylenebilir. Çalışmaların simetrik dağılması yapılan analizin güçlü olduğunu ve yayın yanlılığının olmadığını ifade etmektedir. Yanlılığı belirlemenin önemli yollarından bir diğeri de "Rosenthal'in Güvenli $N$ Testi"dir. Bu testten elde edilen veriler huni grafiğindeki verileri desteklemektedir. Testten elde edilen veriler şu şekildedir:

Tablo 3

Rosenthal FSN Değerine Göre Çalışmaların Yanlılık Durumu

\begin{tabular}{lc}
\hline Çalışmalara ilişkin $Z$ değeri & 17.63661 \\
Çalışmalara ilişkin $p$ değeri & $0.00000^{\mathrm{a}}$ \\
Alfa & 0.05000 \\
Yön & 2.00000 \\
Alfaya ilişkin $Z$ değeri & 1.95996 \\
Çalışma sayısı & 20.00000 \\
Alfaya $p$ değeri getirecek eksik çalışmaların sayısı & 1600.00000 \\
\hline
\end{tabular}
${ }^{\mathrm{a} p} p .05$

Tablo 3 incelendiğinde, meta analiz çalıșmasına ait sonucun anlamlılığını kaybetmesi için etki büyüklük değeri sıfıra eşit olan 1600 çalışmaya daha ihtiyaç olduğu görülmektedir. Diğger bir deyişle 1600 çalışma yapılsın ki $p$ değeri 0,05 'ten büyük olsun. İncelenen çalışma sayısı ile karşılaştırıldığında, Rosenthal FSN değeri büyükse elde edilen sonuçlar yayın yanlılı̆̆ına dirençlidir denilebilir (Üstün \& Eryılmaz, 2014). Matematik öğrenme güçlüğü yaşayan öğrenciler için hazırlanmış müdahale programlarının öğrencilerin akademik başarılarına etkisinin incelendiğinde bu meta analiz çalışmasında Rosenthal FSN değeri incelenen çalışma sayısından büyük olduğu için bu çalışma yayın yanlılığına dirençlidir denilebilir. Yayın yanlılığını belirlemede diğer bir yöntem olan “Orwin'in Güvenli N Yöntemi” de kullanılmış ve Rosenthal ile benzer bulgular tespit edilmiştir. Bu bulgular Tablo 4'te sunulmuştur.

\section{Tablo 4}

Orwin FSN Değerine Göre Çalışmaların Yanlılık Durumu

\begin{tabular}{lc}
\hline Çalışmalara ilişkin Hedge $g$ & 0.78543 \\
"Önemsiz” bir Hedge $g$ için ölçüt & 0.10000 \\
Eksik çalışmalar için ortalama Hedge $g$ & 0.00000 \\
Hedge $g$ değerinin anlamsız olabilmesi için ihtiyaç duyulan çalışma sayısı & 138.00000 \\
\hline
\end{tabular}


Tablo 4'te sunulan bulgular incelendiğinde, Hedge $g$ değerinin anlamsız olabilmesi ve genel etki değerinin önemsiz bir değer alabilmesi için etki büyüklük değeri sıfıra eşit olan 138 çalışmaya daha ihtiyaç vardır. Kabul edilen etki büyüklük değeri sıfırdan 0.005 'e yükseltilirse, etki büyüklük değerinin anlamsız olması için 276 çalışmaya ihtiyaç vardır. Önceden belirlenen farklı Hedge $g$ değerleri için farklı FSN değerleri elde etmek mümkündür.

\section{Heterojenlik Testi ve İstatistiksel Model}

Bir meta analiz çalışmasında amaç, değişkenler arasındaki ilişkinin etki büyüklüğüyle ilgili olarak güven aralığı, istatistiksel anlamlılık ve genel bir değer elde etmek, etki büyüklüklerinin heterojen olup olmadığının belirlenmesi ve etki büyüklükleri arasında heterojenlik varsa sonuca etki edebilecek ara değişkenlerin belirlenmesidir (Huedo-Medina vd., 2006). Bu doğrultuda heterojenliğin test edilmesi, değerlendirilmesi meta analiz çalışmalarında önemli amaçlardan biridir. Çünkü çalışmalar arasında heterojenliğin varlığı ya da yokluğu meta analiz yapan kişinin verilere uygulaması gereken istatistiksel modele karar vermesinde etkilidir (HuedoMedina vd., 2006). Yapılan heterojenlik analizi etki büyüklük değerlerinin yorumlanmasında hangi meta analiz modelinin kullanılması gerektiğiyle ilgili bilgi vermektedir. "Sabit etkiler modeli" kullanılarak elde edilen homojenlik ve heterojenlik analizine ilişkin veriler Tablo 5’te sunulmaktadır.

\section{Tablo 5}

Çalışmalara İlişkin Etki Büyüklük Değgerlerinin Sabit Etkiler Modeli Dikkate Alınarak Hesaplanması

\begin{tabular}{|c|c|c|c|c|c|c|c|}
\hline \multirow{2}{*}{$\begin{array}{l}\text { Ortalama etki } \\
\text { büyüklüğ̈̈ }(g)\end{array}$} & \multirow{2}{*}{$Q$-değeri } & \multirow{2}{*}{$\begin{array}{c}\text { Ki-Kare değeri } \\
\left(x^{2}\right)\end{array}$} & \multirow{2}{*}{$\begin{array}{c}\text { Serbestlik } \\
\text { derecesi }(d f)\end{array}$} & \multirow{2}{*}{$\begin{array}{l}\text { Standart } \\
\text { hata }(S E)\end{array}$} & \multirow[t]{2}{*}{$I^{2}$} & \multicolumn{2}{|c|}{$\begin{array}{c}\text { Hedge } g \text { için \% } 95 \\
\text { güven aralığ1 }\end{array}$} \\
\hline & & & & & & Alt limit & Üst limit \\
\hline 0.762 & 128.394 & 30.144 & 19 & 0.035 & 85.202 & 0.693 & 0.831 \\
\hline
\end{tabular}

Tablo 5'teki veriler incelendiğinde $Q$ istatistik değerine ait hesaplamanın 128.394 olduğu görülmektedir. $\mathrm{Bu}$ değerin, \%95 anlamlılık düzeyinde ki-kare $\left(x^{2}\right)$ tablosunda 19 serbestlik derecesi için öngörülen 30.144 kritik değerin oldukça üzerinde olduğu görülmektedir. Ayrıca $Q$ istatistiğinin meta analizi oluşturan örneklem sayısı az olduğunda, heterojenliği belirlemede yetersiz kaldığ ifade edilmektedir. Heterojenliği tespit etmenin bir diğer yolu ise varyansın toplam varyansa oranını ifade eden $I^{2}$ istatiğine ait bilgilerin sunulmasıdır. Tablo incelendiğinde $I^{2}$ değerinin 85.202 olduğu görülmektedir. Hesaplama sonucu elde edilen $I^{2}$ değeri (85.202) Higgins ve Thompson (2002) tarafından yapılan sınıflamaya göre yüksek düzeyde $\left(I^{2}=75\right)$ heterojenlik değerine sahiptir. Son olarak $p$ değeri $(p=0.000)$ anlamlılık değeri kabul edilen $p=.05$ 'ten küçük bir değer almıştır. Hesaplanan bu değerler $(Q$ $\left.=128.394, p<.05, I^{2}=85.202\right)$ etki büyüklüklerinin heterojen bir dağılım gösterdiğini dolayısıyla bulguların yorumlanmasında rastgele etkiler modelinin kullanılmasının gerekliliğini ortaya koymaktadır.

\section{Bulgular}

Çalışmalara ait etki büyüklük değerleri rastgele etkiler modeli kullanılarak birleştirilmiştir. Bununla birlikte elde edilen bulgular araştırma soruları çerçevesinde ele alınmış ve değerlendirilmiştir. Öğretimsel müdahalelerin öğrencilerin akademik başarılarına etkisinin incelendiği birincil çalışmaların sentezlenmesiyle elde edilen değerler (standart hata, varyans vb.) rastgele etkiler modeli dikkate alınarak, Tablo 6'da sunulmuştur.

Tablo 6

Çalışmalara İlişkin Etki Büyüklük Değerlerinin Rastgele Etkiler Modeli Dikkate Alınarak Hesaplanması

\begin{tabular}{cccccccc}
\hline $\begin{array}{c}\text { Ortalama etki } \\
\text { büyüklüğü }(g)\end{array}$ & $\begin{array}{c}\text { Çalışma } \\
\text { sayısı }(N)\end{array}$ & Varyans $(v)$ & $Z$ değeri & $p$ değeri & Standart hata $(S E)$ & \multicolumn{2}{c}{$\begin{array}{c}\text { Hedge } g \text { için \% 95 güven } \\
\text { aralığ } 1\end{array}$} \\
\hline 0.764 & 24 & 0.019 & 5.553 & 0.000 & 0.138 & 0.494 & Alt limit Ust limit \\
\hline
\end{tabular}

Çalışmalara ilişkin etki büyüklük değerlerinin rastgele etkiler modeline göre düzenlendiği Tablo 6 incelendiğinde, genel etki büyüklük değerinin 0.138 hata ile $g=0.764$ olarak hesaplandığı görülmektedir. Ayrıca genel etki büyüklüğü alt ve üst sınırı $\% 95$ güven aralığında sırasıyla 0.494 ve 1.033 olarak hesaplanmıştır. $Z$ ve $p$ değerleri etki büyüklük değerlerinin anlamlı olduğuna işaret etmektedir $(Z=5.553 ; p=.00)$. Tüm bu veriler doğrultusunda, matematik öğrenme güçlüğü yaşayan öğrenciler için oluşturulan müdahale programlarının öğrencilerin akademik başarılarına geniş düzeyde etki ettiği sonucuna varılabilir. 

ÖĞRENCILERIN AKADEMIK BAŞARILARINA ETKISSININ İNCELENMESİ

\section{Müdahale Türüne Göre Etki Büyüklüklerinin Hesaplanması}

Müdahale türüne ilişkin bulgular, araştırmalarda ele alınan öğretimsel strateji ve düzenlemelerden oluşmaktadır. Bu stratejiler araştırmalarda isimlendirildiği şekliyle ele alınmış ve toplamda 12 müdahale türüne ulaşılmıştır. Matematik öğretiminde kullanılan müdahale türüne göre çalışmaların etki büyüklükleri arasındaki farkın anlamlı olup olmadığına ilişkin bulgular Tablo 7'de sunulmuştur.

Tablo 7

Deneysel İşlemlerde Kullanılan Müdahale Türüne Göre Etki Büyüklüğ̈̈ ve Heterojenlik Testi Verileri

\begin{tabular}{|c|c|c|c|c|c|c|}
\hline \multirow{2}{*}{$\begin{array}{c}\text { Model } \\
\text { Rastgele etkiler modeli }\end{array}$} & \multicolumn{3}{|c|}{ \%95 Güven aralığ1 } & \multirow{2}{*}{ Serbestlik derecesi $(d f)$} & \multicolumn{2}{|c|}{ Heterojenlik testi } \\
\hline & Hedge $g$ & Alt limit & Üst limit & & $Q$ değeri & $p$ değeri \\
\hline Bireyselleştirilmiş öğretim & 0.900 & 0.478 & 1.323 & \multirow{12}{*}{11} & \multirow{12}{*}{44.110} & \multirow{12}{*}{0.000} \\
\hline Şema tabanlı öğretim & 0.881 & 0.493 & 1.269 & & & \\
\hline Somut-temsil-soyut öğretim & 1.017 & 0.368 & 1.666 & & & \\
\hline Bilgisayar destekli öğretim & 0.477 & 0.232 & 0.721 & & & \\
\hline Nöropsikolojik müdahale & 4.843 & 3.353 & 6.332 & & & \\
\hline $\begin{array}{l}\text { QuickSmart matematik } \\
\text { müdahalesi }\end{array}$ & 0.840 & 0.190 & 1.491 & & & \\
\hline Geliştirilmiş bağlantılı öğretim & 0.806 & 0.342 & 1.270 & & & \\
\hline Tier 2 müdahale programı & 0.148 & -0.418 & 0.714 & & & \\
\hline Kesir müdahale programı & 0.932 & 0.385 & 1.478 & & & \\
\hline Bilişsel strateji müdahalesi & 0.673 & -0.135 & 1.482 & & & \\
\hline Kelime problem müdahalesi & 0.110 & -0.522 & 0.741 & & & \\
\hline Öz düzenleme öğretimi & 0.982 & 0.210 & 1.754 & & & \\
\hline
\end{tabular}

Tablo 7'de sunulan değerler incelendiğinde etki büyüklük değerlerinin tümünün pozitif olduğu ve genellikle yüksek düzeyde değere sahip oldukları ifade edilebilir. Nöropsikolojik müdahaleye ait etki büyüklük değerinin $(g=4.843)$ diğer müdahale türlerine ait değerlerden daha yüksek düzeyde bir etkiye sahip olduğu ve uç bir değer aldığı görülmektedir. Bu müdahale türünü somut-temsil-soyut öğretim $(g=1.017)$, öz düzenleme öğretimi ( $g=0.982)$, kesir müdahale programı $(g=0.932)$, bireyselleştirilmiş öğretim $(g=0.900)$, şema tabanlı öğretim $(g=0.881)$, QuickSmart matematik müdahalesi $(g=0.840)$ ve geliştirilmiş bağlantılı öğretim $(g=0.806)$ değişkenleri takip etmektedir. Tier 2 müdahale programı $(g=0.148)$ ve kelime problem müdahalesi $(g=0.110)$ ise zayıf düzeyde etki büyüklük değerlerine sahiptir. Son olarak, etki büyüklüklerinin oluşturulan müdahale türüne göre farklılaşıp farklılaşmadığına bakıldığında $Q=44.110$ değerinin $\% 95$ anlamlılık düzeyinde $x^{2}$ tablosunda 11 serbestlik derecesiyle belirlenen 26.756 değerinden yüksek olması, akademik başarının, öğrenme-öğretme sürecinde kullanılan öğretim yöntemlerine göre anlamlı bir farklılık oluşturduğuna işaret etmektedir.

\section{Tanılama Yöntemlerine İlişkin Bulgular}

Tanılama yöntemlerine ilişkin bulgular, matematik öğrenme güçlüğü yaşayan öğrencilerin belirlenmesinde kullanılan tanılama yöntemlerinden oluşmaktadır. Tanılama yöntemleri araştırmalarda isimlendirildiği şekliyle ele alınmış ve toplamda 15 farklı yönteme ulaşılmıştır. Bu yöntemlere ilişkin bulgular Tablo 8'de sunulmuştur.

\section{Tablo 8}

Matematik Öğrenme Güçlüğ̈̈ Yaşayan Öğrencilerin Belirlenmesinde Kullanılan Yöntemlere İlişkin Veriler

\begin{tabular}{|c|c|c|c|}
\hline & Katılımcıların belirlenmesinde kullanılan yöntemler & $n$ & Yüzde (\%) \\
\hline \multirow{9}{*}{ Tanılama yöntemi } & Matematik başarı testi & 6 & 19.35 \\
\hline & Bilişsel Yetenek Değerlendirme Sistemi & 2 & 6.45 \\
\hline & Wechsler Kısaltılmış Zekâ Ölçeği (WASI-IQ) & 6 & 19.35 \\
\hline & Woodcock-Johnson III başarı testi & 1 & 3.22 \\
\hline & Iowa temel beceri testi (ITBS) & 2 & 6.45 \\
\hline & Texas Erken Matematik Envanterleri-İlerleme İzleme (TEMI-PM) & 1 & 3.22 \\
\hline & Müfredat temelli değerlendirme & 2 & 6.45 \\
\hline & Geniş Kapsamlı Başarı Testi-3 (WRAT-3) & 1 & 3.22 \\
\hline & Geniş Kapsamlı Başarı Testi-4 (WRAT-4) & 2 & 6.45 \\
\hline
\end{tabular}


Tablo 8 (devami)

\begin{tabular}{llll}
\hline & \multicolumn{1}{c}{ Katılımcıların belirlenmesinde kullanılan yöntemler } & $n$ & Yüzde (\%) \\
\hline & Grup Matematik Ölçme ve Tanılama Değerlendirme Süreci ve & 1 & 3.22 \\
& Uygulamaları alt testi & 1 & 3.22 \\
\multirow{3}{*}{ Tanılama yöntemi } & Matematik Yetenek Testi (TOMA) & 3 & 9.67 \\
& KeyMath değerlendirmesi & 1 & 3.22 \\
& Gözlem & 1 & 3.22 \\
\hline
\end{tabular}

Tablo 8'de verilen bulgular incelendiğinde, matematik öğrenme güçlüğü yaşayan öğrencilerin belirlenmesinde farklı yöntem ve tekniklerden yararlanıldığı görülmektedir. Matematik öğrenme güçlüğü yaşayan öğrencilerin belirlenmesinde başarı testi, yetenek testi, zekâ ölçeği ve çeşitli değerlendirme sistemlerinden yararlanılmıştır. Bulgular incelendiğinde güçlük yaşayan öğrencilerin belirlenmesinde en sık matematik başarı testi $(n=6)$ ve Wechsler kısaltılmış zekâ ölçeğinin $(n=6)$ kullanıldığı görülmektedir. Bunlarla birlikte KeyMath değerlendirmesi $(n=3)$, bilişsel yetenek değerlendirme sistemi $(n=2)$, Iowa temel beceri testi $(n=2)$ ve müfredat temelli değerlendirmenin $(n=2)$ de matematik öğrenme güçlüğü yaşayan öğrencilerin belirlenmesinde kullanıldığ görülmektedir. Son olarak, güçlük yaşayan öğrencilerin belirlenmesinde 14 farklı yöntemden yararlanılmıştır.

\section{Matematik Öğrenme Alanlarına Göre Etki Büyüklüklerinin Hesaplanması}

Öğrenme alanlarına ilişkin bulgular, matematik öğrenme güçlüğü yaşayan öğrenciler için hazırlanan müdahale programlarında kullanılan matematik öğrenme alanlarından oluşmaktadır. Öğrenme alanına ilişkin bulgular, sayı algısı, kesirler, geometri-ölçme, cebir ve problem çözme öğrenme alanlarından oluşmaktadır. Çalışmalara ait etki büyüklük değerlerinin öğrenme alanlarına göre anlamlı bir fark oluşturup oluşturmadığıyla ilgili bulgular Tablo 9'da sunulmuştur.

\section{Tablo 9}

Matematik Öğretiminin Gerçekleştirildiği Öğrenme Alanına Göre Etki Büyüklükleri ve Heterojenlik Testi Verileri

\begin{tabular}{lcccccc}
\hline \multicolumn{1}{c}{ Model } & \multicolumn{3}{c}{$\%$ G5 Güven aralı̆̆ } & \multirow{2}{*}{ Serbestlik derecesi $(d f)$} & \multicolumn{2}{c}{ Heterojenlik testi } \\
\cline { 1 - 3 } Rastgele etkiler modeli & Hedge $g$ & Alt limit & Üst limit & & & \\
\cline { 1 - 4 } Sayı bilgisi & 0.822 & 0.497 & 1.147 & & \\
Problem çözme & 0.540 & 0.095 & 0.985 & & \multirow{2}{*}{0.605} \\
Kesirler & 0.915 & 0.459 & 1.371 & & \\
Geometri-ölçme & 0.818 & 0.003 & 1.634 & & \\
Cebir & 0.245 & -0.676 & 1.167 & & \\
\hline
\end{tabular}

Tablo 9 incelendiğinde, matematik öğretiminin gerçekleştirildiği öğrenme alanlarına ait etki büyüklüklerinin pozitif olduğu görülmektedir. Kesirler öğrenme alanına yönelik etki büyüklük değerinin $(g=$ 0.915) diğer öğrenme alanlarına göre daha yüksek olduğu ve oldukça yüksek düzeyde bir etkiye sahip olduğu görülmektedir. Bu öğrenme alanını sırasıyla sayı bilgisi $(g=0.822)$, geometri-ölçme $(g=0.818)$ ve problem çözme $(g=0,540)$ öğrenme alanlarının takip ettiği ve yüksek düzeyde bir etkiye sahip oldukları görülmektedir. En düşük etki büyüklük değeri ise cebir öğrenme alanında $(g=0.245)$ hesaplanmıştır. Birincil çalışmalardan elde edilen etki büyüklüklerinin matematik öğretiminin gerçekleştirildiği öğrenme alanına göre anlamlı bir farklılık gösterip göstermediğine dair $Q=2.724$ değeri $\% 95$ anlamlılık düzeyinde $x^{2}$ tablosunda 4 serbestlik derecesiyle 9.488 olarak hesaplanmıştır. Değişkenler arasındaki $Q$ değerinin belirlenen kritik değerden düşük olması akademik başarının matematik öğretiminin gerçekleştirildiği öğrenme alanlarına göre anlamlı bir farklılık göstermediğine işaret etmektedir.

\section{Öğretim Düzeylerine Göre Etki Büyüklüklerinin Hesaplanması}

Öğretim düzeyine ilişkin bulgular, öğretimsel müdahalelerin uygulandığı öğretim düzeylerinden oluşmaktadır. Bu bulgular, ilkokul ve ortaokul düzeylerinde şekillendirilmiştir. Çalışmalara ait etki büyüklük değerlerinin öğretim düzeylerine göre anlamlı bir fark oluşturup oluşturmadığıyla ilgili bulgular Tablo 10'da sunulmuştur. 
Tablo 10

Müdahalenin Gerçekleştiği Öğretim Düzeyine Göre Etki Büyüklükleri ve Heterojenlik Testi Verileri

\begin{tabular}{|c|c|c|c|c|c|c|}
\hline \multirow{2}{*}{$\frac{\text { Model }}{\text { Rastgele etkiler modeli }}$} & \multicolumn{3}{|c|}{ \%95 Güven aralığ 1} & \multirow{2}{*}{ Serbestlik dercesi $(d f)$} & \multicolumn{2}{|c|}{ Heterojenlik testi } \\
\hline & Hedge $g$ & Alt limit & Üst limit & & $Q$ değeri & $p$ değeri \\
\hline İlkokul & 0.724 & 0.494 & 0.954 & 1 & 0092 & 0761 \\
\hline Ortaokul & 0.799 & 0.370 & 1.228 & 1 & 0.092 & 0.761 \\
\hline
\end{tabular}

Tablo 10 incelendiğinde, müdahalenin gerçekleştiği öğretim düzeylerine ilişkin etki büyüklüklerinin pozitif bir değere sahip olduğu göze çarpmaktadır. İlkokul $(g=0.724)$ ve ortaokula $(0.799)$ ait etki büyüklük değerlerinin birbirlerine yakın bir değere sahip olduğu görülmektedir. Ayrıca her iki öğretim düzeyine ait etki büyüklük değerinin yüksek düzeyde etkiye sahip olduğu görülmektedir. Çalışmalara ait etki büyüklük değerlerinin müdahalenin gerçekleştirildiği öğretim düzeyine göre anlamlı bir farklılık gösterip göstermediğine dair $Q=0.092$ değeri \%95 anlamlılık düzeyinde $x^{2}$ tablosunda 1 serbestlik derecesiyle 3.841 olarak hesaplanmıştır. Hesaplanan kritik değerin değişkenler arasındaki $Q$ değerinden büyük olması akademik başarının müdahalenin gerçekleştirildiği öğretim düzeyine göre anlamlı bir farklılık göstermediğine işaret etmektedir.

\section{Müdahale Programının Süresine Göre Etki Büyüklüklerinin Hesaplanması}

Öğretimsel müdahale programlarının süresine ilişkin bulgular, müdahale programlarının uygulama süresiyle ilişkilidir. Bu bulgular, kısa süreli, orta süreli ve uzun süreli olmak üzere üç başlıkta incelenmiştir. Çalışmalara ait etki büyüklük değerlerinin müdahale programlarının süresine göre anlamlı bir fark oluşturup oluşturmadığıyla ilgili bulgular Tablo 11'de sunulmuştur.

\section{Tablo 11}

Müdahale Programının Süresine Göre Etki Büyüklükleri ve Heterojenlik Testi Verileri

\begin{tabular}{|c|c|c|c|c|c|c|}
\hline \multirow{2}{*}{$\begin{array}{c}\text { Model } \\
\text { Rastgele etkiler modeli }\end{array}$} & \multicolumn{3}{|c|}{ \%95 Güven aralığı $(95 \% C I)$} & \multirow{2}{*}{ Serbestlik derecesi $(d f)$} & \multicolumn{2}{|c|}{ Heterojenlik testi } \\
\hline & Hedge $g$ & Alt limit & Üst limit & & $Q$ değeri & $p$ değeri \\
\hline Kısa süreli (1-7 oturum) & 0.781 & 0.173 & 1.389 & & & \\
\hline Orta süreli (8-28 oturum) & 0.861 & 0.531 & 1.191 & 2 & 0.982 & 0.612 \\
\hline Uzun süreli (28+ oturum) & 0.641 & 0.350 & 0.932 & & & \\
\hline
\end{tabular}

Tablo 11 incelendiğinde, müdahale programının süresine ilişkin etki büyüklük değerlerinin pozitif olduğu görülmektedir. Orta süreli müdahale programına ait etki büyüklük değerinin ( $g=0.861)$ diğer oturum sürelerine göre daha yüksek bir değere sahip olduğu göze çarpmaktadır. Bu etki değerini, kısa süreli oturuma ait etki değerleri ( $g=0.781)$ ve uzun süreli oturumlara ait etki değerleri $(g=0.641)$ takip etmektedir. Heterojenlik testine ilişkin $Q$ $=0.982$ değeri $\% 95$ anlamlılık düzeyinde $x^{2}$ tablosunda 2 serbestlik derecesiyle 5.991 olarak hesaplanmıştır. Değişkenler arasındaki $Q$ değerinin belirlenen kritik değerden düşük olması akademik başarının müdahale süresine göre anlamlı bir farklılık göstermediğine işaret etmektedir.

\section{Tartışma}

Bu çalışmanın amacı, 2003-2020 yılları arasında yayınlanan deneysel ve yarı deneysel çalışmaların matematik öğrenme güçlüğü yaşayan öğrenciler üzerindeki etkilerini sentezleyerek daha önce yapılan çalışmaları genişletmektir. Ayrıca bu çalışma, güçlük yaşayan öğrencilerin belirlenmesinde kullanılan yöntemler ve müdahale türlerinin müdahale etkileri üzerindeki etkisini analiz ederek önceki çalışmaları da genişletmiştir. Aşağıda, bu çalışmada ortaya çıkan her bir araştırma sorusunun tartışması sunulmaktadır.

Çalışmalara ait etki büyüklük değerleri incelendiğinde, tüm araştırmalara ilişkin etki büyüklük değeri 0 , 764 olarak hesaplanmıştır. Bu değer öğretimsel müdahalelerin matematik öğrenme güçlüğü yaşayan öğrencilerin matematik performansı üzerinde genel anlamda olumlu bir etkiye sahip olduğunu göstermektedir. Bu bulgu daha önce yapılan çalışmalarla benzerlik göstermektedir (Dennis vd., 2016; Jitendra vd., 2018; Küçükalkan vd., 2019; Stevens vd., 2017). Çalışmalar müdahale türü, tanılama ölçütü, öğrenme alanı, öğretim düzeyleri ve müdahale programının süresi gibi değişkenler bakımından farklılık gösterdiğinden, etki büyüklüklerinin farklı değişkenleri nasıl etkilediği dikkate alınması gereken bir diğer konudur.

\section{Müdahale Türü}

Çalışmalardan elde edilen etki büyüklük değerleri kullanılan müdahale türüne göre anlamlı düzeyde farklılaşmaktadır. Müdahale türüne ilişkin bulgular incelendiğinde, nöropsikolojik müdahaleye ait etki büyüklük 
değerinin oldukça yüksek olduğu görülmektedir. Bu değişkene ait bir diğer sonuç ise, somut-temsil-soyut öğretim, öz düzenleme öğretimi, kesir müdahale programı, bireyselleştirilmiş öğretim, şema tabanlı öğretim ve geliştirilmiş bağlantılı öğretimin matematik öğrenme güçlüğü yaşayan öğrencilerin matematik öğretimlerinde yüksek bir etkiye sahip olduğudur. Bu sonuçlar literatürde yapılan çeşitli araştırmalar tarafından desteklenmektedir (Monei \& Pedro, 2017; Marita \& Hord, 2016; Chodura vd., 2015; Gersten vd., 2009). Bu anlamlı farklılı̆̆ın oluşmasında etkisi olan bir diğer değişken de bilgisayar destekli öğretimdir. Bilgisayar destekli öğretim, matematik öğrenme güçlüğü yaşayan öğrencilerin matematik öğretiminde orta düzeyde bir etkiye sahiptir. Daha önceki çalışmalar bu sonucu destekler niteliktedir (Chodura vd., 2015; Jitendra vd., 2018; Küçükalkan vd., 2019; Li \& Ma, 2010; Stevens vd., 2017; Stultz, 2017). Ayrıca bilgisayar destekli öğretim başlığ 1 altında matematik öğrenme güçlüğü yaşayan öğrencilerin matematik öğretimlerinde görsel temsillerden yararlanıldığı ifade edilmektedir (Stevens vd., 2017). Müdahale türü açısından meta analiz sonuçları incelendiğinde, sonuçların farklılık gösterdiği ifade edilebilir. Tek bileşenli müdahaleler (sadece doğrudan) sınırlı bilişsel, davranışsal ve dikkat kapasiteleri nedeniyle sınırlı etkiye sahiptir (Fuchs vd., 2014). Diğer yandan çok bileşenli müdahaleler (diğer stratejilerle birleştirilmiş doğrudan öğretim) daha güçlü etkiler oluşturabilir (Lee vd., 2020). Okuma güçlüğüne ilişkin müdahalelerin analizi bu görüşü desteklemektedir (Wanzek vd., 2010). Çalışmalarda kullanılan müdahale türüne ilişkin en düşük değere sahip olan değişken Tier 2 müdahale programı ve kelime problem müdahaleleridir. Bu sonuç, Seo ve Bryant (2009) tarafından yapılan sonuçla tutarlı olmakla beraber Kiru ve diğerleri (2018) tarafından yapılan araştırma sonucuyla çelişmektedir. Teknoloji cihazlarına adaptasyon süreci bu müdahaleye ilişkin etki büyüklük değerinin düşük çıkmasının bir sebebi olabilir. Matematik öğrenme güçlüğü yaşayan öğrencilerin desteklenmesi amacıyla farklı öğretimsel müdahalelerin geliştirildiği görülmektedir. Ancak, bu müdahalelere rağmen güçlükler devam ettiğinde bir sonraki müdahale adımları açık değildir (Gillum, 2014). Ancak geliştirilen öğretimsel müdahaleler, öğrencilere matematik öğretim sürecinde destek olmakla beraber matematik öğrenme güçlüğü üzerine farkındalık oluş̧urmaya devam etmektedir (Monei \& Pedro, 2017).

\section{Tanılama Ölçütleri}

Öğrenme güçlüğü olan öğrencilerin çoğu genel eğitim sınıflarında eğitim ve öğretimine devam etmektedir. Bu öğrenciler için genel eğitim ortamlarında gerekli düzenlemeler yapılamamakta ve öğretmenlere bu konuda rehber olunamamaktadır (Özmen, 2018). Matematik öğrenme güçlüğü yaşayan öğrencilerin erken yaşta belirlenmesi ve bireysel öğretimsel müdahalelerin geliştirilmesi ve uygulanması matematik öğretimi açısından önemlidir. Ancak, matematik öğrenme güçlüğünün hem tanımında hem de tanılanmasında üzerinde görüş birliğine varılmış bir yaklaşım mevcut değildir. Tanılamaya ilişkin farklı görüş ve yaklaşımlar incelendiğinde, bireyler için hazırlanacak öğretimsel müdahalelere yeterli veri sağlayamadıkları ifade edilebilir. Çalışmalar ayrıntılı yapılan bir tanılamanın doğru odaklı bir müdahaleye de rehberlik edebileceğini ifade etmektedir (Ashlock, 2015; Kaufmann vd., 2013). Öğrenme güçlüğü yaşayan öğrencilerin bireysel özelliklerini ortaya çıkarmak için tanılama ve değerlendirmede testler, görüş̧meler ve diğer değerlendirme araçları gibi farklı yöntem ve değişkenlerin kullanılması önemlidir (Mutlu \& Akgün, 2017). Bu doğrultuda bireyin doğru tanı alması sağlanabilir.

Ülkemizde tanılama uygulamaları ve bu öğrencilerin bireysel özelliklerine uygun özel eğitim hizmetlerine erişimlerinin henüz yeterli olmadığı ifade edilmektedir (Özmen, 2014). Tanılamada yeterli ölçü araçlarının olmaması bu durumun ortaya çıkmasında önemli bir faktör olarak görülebilir. Tıbbi tanılama sürecinde kullanılan zekâ ve algı testleriyle bir bakıma psikolojik süreç değerlendirmesiyle öğrenciler tanılanmaktadır. Tıbbi tanılamanın eğitsel tanılamayla birleştirilememesi nedeniyle tanılamada tutarsızlıklar yaşanmaktadır. Tanılamada yaşanan tutarsızlıklar, bir yıl zihinsel yetersizlik tanısı olan bir çocuğun bir sonraki yıl öğrenme güçlüğü olarak tanılanmasına ya da tam tersi durumun ortaya çıkmasına, öğrenme güçlüğü olmayan öğrencilerin öğrenme güçlüğü olarak tanılanmasına neden olmaktadır (Özmen, 2018). Öğrenme güçlügünün tanılanması güç olan bir yetersizlik grubu olması ve bu grupta bulunan öğrencilerin farklı özellikler sergilemesi sadece formal değerlendirme (yetenek ve başarı testi) sonuçlarına bağlı kalınmamasını ve formal değerlendirme sonuçlarının sınıfta yapılan değerlendirmeler (ölçüt bağımlı testler, müfredat temelli değerlendirme, gözlem) yolu ile desteklenmesini gerekli kılmaktadır.

\section{Öğrenme Alanı}

Matematik öğrenme alanına ilişkin maderatör analizi sonuçları incelendiğinde, öğretimsel müdahalelerin matematik öğrenme alanlarına göre anlamlı bir farklılık oluşturmadığı sonucuna ulaşılmıştır. Ayrıca kesirler ve sayı bilgisi öğrenme alanlarına ilişkin etki büyüklük değerlerinin yüksek bir etki değerine sahip olduğu, cebir öğrenme alanına iliş̧in etki büyüklük değerinin zayıf bir etkiye sahip olduğu sonucu elde edilmiştir. Bu sonuç Stevens ve diğerleri (2017) ve Dennis ve diğerleri (2016) tarafından yapılan araştırma sonuçlarıyla benzerlik 
göstermektedir. Matematik öğrenme alanlarına ilişkin veriler incelendiğinde müdahalelerin genel olarak sayı algısı öğrenme alanına odaklandığı görülmektedir. MÖG yaşayan öğrencilerin temel aritmetiksel kavram ve becerilerde güçlük yaşaması, araştırmaya dâhil edilen çalışmaların genellikle ilkokul düzeyinde olması bu bulgunun ortaya çıkmasının sebebi olabilir. Temel aritmetik becerilerin diğer becerilere temel teşkil ettiği düşünüldüğünde bu sonucun şaşırtıcı olmadığı görülebilir. Ayrıca öğrenme alanlarına ilişkin etki büyüklük değerlerinin tüm öğrenme alanlarında yüksek olduğu görülmüştür. Dolayısıyla, geliştirilen öğretimsel müdahalelerin, matematik öğrenme alanı bağlamında öğrenci başarılarını etkilediği ifade edilebilir. Zayıf etki büyüklüğüne sahip tek öğrenme alanı ise, cebir öğrenme alanıdır. Cebir öğrenme alanına ilişkin elde edilen sonuçlar, literatürle karşılaştırıldığında çeliştiği görülmektedir (Lee vd., 2020; Stevens vd., 2017). Bu farklılığın ortaya çıkmasında, meta analize dâhil edilen çalışmaların farklı olması, çalışmalarda farklı öğretim bileşenlerinin incelenmesi gerekçe olarak gösterilebilir. Örneğin Lee ve diğerleri (2020) tarafından yapılan çalışmada çoklu temsiller (somut ve sanal materyaller, resimler) ve açık öğretim bileşenleri öğretimsel müdahale olarak kullanılmıştır. Ayrıca cebir kavramları ve becerileri, öğrencilerin yükseköğretimde ve istihdamda başarı için öğrenmeleri gereken bir konudur. Cebir öğrenme alanına ilişkin yoğunluğu ve süresi artırılmış kanıt temelli öğretimsel uyarlamalara ihtiyaç vardır (Lee vd., 2020). Cebir öğrenme alanına yönelik sadece iki çalışma yapılmıştır (Swanson vd., 2013). Cebir öğrenme alanına ilişkin farklı öğretim bileşenleriyle daha fazla çalışma yapılabilir. Ayrıca yapılan çalışmalar belirli bir içerik alanını hedef alan çalışmalardan oluşmaktadır. Öğrenciler belirli bir içerik alanını hedef alan müdahalelere o konuya ilişkin becerilerdeki yetersizlik sebebiyle cevap veremezler (Stevens vd., 2017). Bu nedenle birden fazla beceri alanını hedef alan müdahaleleri araştırmak önemli görülebilir.

\section{Öğretim Düzeyleri}

Öğretim düzeyine ait etki büyüklük değerleri incelendiğinde, matematik öğrenme güçlüğü yaşayan öğrenciler için geliştirilen öğretimsel müdahalelerin öğretim düzeyi bağlamında öğrenciler üzerinde anlamlı bir farklılık göstermediği sonucu ortaya çıkmaktadır. Ayrıca, öğretim düzeyine ait etki büyüklük değerleri incelendiğinde değerler birbirine yakın olmakla beraber ortaokul düzeyine ait etki büyüklük değerinin yüksek olduğu görülmüştür. Ulaştığımız sonuç, literatüre ilişkin bilgilerle uyuşmamaktadır. Araştırmalar, öğretim düzeyi arttıkça matematik içeriklerinin karmaşıklığı aratacağından, müdahalelerin ilkokul öğrencilerinde daha güçlü etki oluşturmasını öngörmektedir (Jitendra vd., 2018; Chodura vd., 2015; Gersten vd., 2009). Bu durumun araştırmaya dâhil edilen çalışmaların metodolojik özelliklerinden kaynaklandığı düşünülebilir. Nitekim, araştırmaya dahil edilen yarı deneysel çalışmaların şişirilmiş etki büyüklüklerine sebep olabileceği ifade edilmektedir (Gersten vd., 2009; Jitendra vd., 2018). Meta analizin istatistiksel gücünü azaltabilecek olan bu bulgunun ortaya çıkmasında, tüm çalışmaların analize dâhil edilmemesi gerekçe gösterilebilir. Bir diğer önemli sonuç ise ilkokul düzeyinde gerçekleştirilen matematik müdahalelerinin ortaokulda gerçekleştirilen müdahalelerden oldukça fazla olmasıdır. İlkokulda gerçekleştirilen müdahale çalışmalarının sayıca fazla olması erken müdahale ve teşhisin öneminden kaynaklanmakta olabilir.

\section{Müdahale Programının Süresi}

Müdahale programının süresine ilişkin moderatör analizinden elde edilen sonuçlar, müdahale süresinin öğrenci başarısı üzerinde anlamlı bir farklılık oluşturmadığı yönündedir. Sonuçlar, orta ve kısa süreli oturumların uzun süreli oturumlardan daha yüksek bir etki oluşturduğunu göstermektedir. Bu durumun ortaya çıkmasında, araştırmaya dâhil edilen çalışmaların sınırlı olması ve ilkokul düzeyinde daha fazla araştırmanın incelenmesi sebep olarak gösterilebilir. Araştırma sonuçları özellikle daha üst düzeyde matematiksel becerilerin öğretilmesinde öğrencilerin uzun süre müdahaleye dâhil edilmesi gerektiğini ortaya koymaktadır (Jitendra vd., 2018). Matematik öğrenme güçlüğü yaşayan öğrenciler için yoğunluğu ve içeriği artırılmış müdahaleler öğrencilerin matematik performansında artış sağlamaktadır (Bryant vd., 2008; Stevens vd., 2017). Müdahale süresinin uzatılması ve grup büyüklüğünün azaltılması müdahalenin yoğunlaştırılması için yaygın yöntemlerdir (Stevens vd., 2017). Müdahaleye yanıt vermeyen öğrenciler için öğretimi yoğunlaştırma önemli görülmektedir. Bu çalışmadan elde edilen sonuçlar öğrencilerin matematiksel içerik öğrenirken uzun süre öğrenmeye katılma gereksinimlerini doğrulamaktadır (Jitendra vd., 2018). Öğrencilerin sorumlu oldukları matematik becerilerinin giderek arttı̆̆1 göz önüne alındığında öğrenciler ortaokulda daha fazla yoğunluğa ve süreye sahip müdahalelere ihtiyaç duymaktadır (Jitendra vd., 2018; Stevens vd., 2017). Çünkü matematik öğrenme güçlüğü yaşayan öğrencilerin sinıf düzeyleri arttıkça normal gelişim gösteren akranlarıyla aralarındaki fark giderek açılmaktadır (Stevens vd., 2017; Wei vd., 2013). 


\section{Sınırlamalar ve Gelecekteki Yönelimler}

Yapılan meta analiz çalışmasının bazı sınırlamaları ve gelecekte yapılacak araştırmalar için bazı önerileri vardır. İlk olarak, son 17 yılın (2003-2020) incelendiği bu meta analiz çalışmasına deneysel ve yarı deneysel 24 çalışma dâhil edilmiştir. Bu sayı okuma müdahaleleriyle karşılaştırıldığında nispeten sınırlı kalmaktadır. Gelecekteki çalışmalar, matematiğin önemi göz önüne alındığında (Hughes vd., 2014), matematik öğrenme güçlüğü yaşayan öğrenciler için daha fazla etkili matematiksel müdahale çalışmaları üzerine odaklanabilir. Bununla beraber okul yönetimini bilgilendirmek, müdahalelerin gelişimini sağlamak ve bunların uygulanmasını geliştirmek için matematik öğrenme güçlüğüne yönelik çeşitli öğretim stratejileriyle daha fazla çalışma yapmaya ihtiyaç vardır (Monei \& Pedro, 2017). Matematik öğrenme güçlüğü yaşayan öğrencilerin ihtiyaçlarını nasıl karşılayacaklarını ortaya koymak ve müdahale sonuçlarını iyileștirmek amacıyla daha fazla çalışma yapılabilir. Ayrıca yarı deneysel çalışmalardan elde edilen sonuçlarla genellemelere varılması olası sınırlamalara neden olmaktadır. Hangi öğretimsel müdahalenin matematik öğrenme güçlüğü yaşayan öğrenciler üzerinde daha etkili olduğuna ilişkin daha fazla araştırma yapmaya ihtiyaç olduğu ifade edilebilir. Ayrıca metodolojik kalite etkili öğretimsel yaklaşımlar hakkında çıkarım yapmamızı etkileyebileceğinden, daha yüksek kaliteli metodolojik çalışmalar matematik öğrenme güçlüğü yaşayan öğrenciler için etkili yaklaşımlar ve öğretim bileşenleri hakkında daha iyi bir tablo sunabilir.

İkinci olarak, analize sadece deneysel ve yarı deneysel çalışmalar dâhil edilmiştir. Seçim ölçütlerimiz doğrultusunda matematik öğrenme güçlüğü yaşayan öğrenciler için hazırlanan müdahale programlarının etkililiğini inceleyen çok sayıda tek denekli çalışma araştırmaya dâhil edilmemiştir. Ayrıca sentezimizde sadece makale türü çalışmalara yer verilmiştir. Bu sınırlamaları ortadan kaldırmak için tek denekli çalışmaların da dâhil edildiği çeşitli çalışma türlerine (tez, bildiri vs.) yer veren geniş örnekleme sahip araştırmalar yapılabilir. Üçüncü olarak, matematik öğrenme güçlüğü yaşayan öğrencilerin değerlendirilmesi ve belirlenmesi için kullanılan ölçütlerin gözden geçirilmesi gerekmektedir. Matematik öğrenme güçlüğü yaşayan katılımcıların yetersiz ve tutarsız bir şekilde tanılanması nedeniyle birkaç müdahale çalışması araştırmaya dâhil edilmemiştir. Farklı birçok çalışmada, matematik öğrenme güçlüğü yaşayan öğrencilerin belirlenmesinde, matematik becerileri için herhangi bir standart tarama testi yapmadan okul veya öğretmenlerin görüşleri dikkate alınmıştır. Yapılan çalışmalarda, matematik öğrenme güçlüğü yaşayan öğrencilerin belirlenmesinde standart tarama testleri, yetenek ve başarı testi gibi formal değerlendirmelerle birlikte sınıf içi değerlendirmelerden de yararlanılabilir. 


\section{Kaynaklar}

Akçin, N. (2019). Öğrenme güçlüğü olan öğrenciler için genel eğitim sınıflarında uygulanacak etkili öğretimsel stratejiler ve öğretimsel düzenlemeler. E. R. Özmen \& A. Ataman (Eds.), Öğrenme güçlüğ̈̈ ve özel yetenek [Learning disability and special ability] içinde (ss. 55-89). Maya Akademi.

Akın, Ş. A., \& Özmen, E. R. (2019). Öğrenme güçlüğünün tanılanması ve karşılaşılan sorunlar. E. R. Özmen \& A. Ataman (Ed.), Öğrenme güçlüğü ve özel yetenek [Learning disability and special ability] içinde (ss. 1-24). Maya Akademi.

American Psychiatric Association. (2013). Diagnostic and statical manual of mental disorders: DSM-5. American Psychiatric Publishing.

Arthur, W. Jr., Bennett, W. Jr., \& Huffcutt, A. I. (2001). Conducting meta-analysis using SAS. Lawrence Erlbaum Associates Inc.

Ashlock, R. B. (2015). Deep diagnosis, focused instruction, and expanded math horizons. In S. Chinn (Ed.), The Routledge international handbook of dyscalculia and mathematical learning difficulties (pp. 228-234). Routledge.

Baker, S., Gersten, R., \& Lee, D. S. (2002). A synthesis of empirical research on teaching mathematics to lowachieving students. Elementary School Journal, 103(1), 51-73. https://doi.org/10.1086/499715

*Bellert, A. (2009). Narrowing the gap: A report on the quick smart mathematics intervention. Australian Journal of Learning Difficulties, 14(2), 171-183. https://doi.org/10.1080/19404150903264310

Bender, W. N. (2016). Öğrenme güçlüğ̈̈ olan bireyler ve eğitimleri [Individuals with learning difficulties and their education] (6. baskı). (H. Sarı, Çev.). Nobel Akademik Yayıncılık.

Berkeley, S., Scruggs, T. E., \& Mastropieri M. A. (2010). Reading comprehension instruction for students with learning disabilities, 1995-2006: A meta-analysis. Remedial and Special Education, 31(6), 423-436. https://doi.org/10.1177/0741932509355988

Bird, R. (2017). The dyscalculia toolkit: Supporting learning difficulties in maths. Sage Publications.

Borenstein, M., Hedges, L. V., Higgins, J. P., \& Rothstein, H. R. (2013). Meta analize giriş [Introduction to Metaanalysis]. (S. Dinçer, Çev.). Anı Yayıncılık.

*Bottge, B. A., Rueda, E., Grant, T. S., Stephens, A. C., \& Laroque, P. T. (2010). Anchoring problem-solving and computation instruction in context-rich learning environments. Exceptional Children, 76(4), 417-437. https://doi.org/10.1177/001440291007600403

*Bottge, B. A., Toland, M. D., Gassaway, L., Butler, M., Choo, S., Griffen, A. K., \& Ma, X. (2015). Impact of enhanced anchored instruction in inclusive math classrooms. Exceptional Children, 81(2), 158-175. https://doi.org/10.1177/0014402914551742

Bryant, D. P., Bryant, B. R., Gersten, R., Scammacca, N., \& Chavez, M. M. (2008). Mathematics intervention for first- and second-grade students with mathematics difficulties: The effects of tier 2 intervention delivered as booster lessons. Remedial and Special Education, 29(1), 20-32. https://doi.org/10.1177/0741932507309712

*Bryant, D. P., Bryant, B. R., Roberts, G., Vaughn, S., Pfannenstiel, K. H., Porterfield, J., \& Gersten, R. (2011). Early numeracy intervention program for first-grade students with mathematics difficulties. Exceptional Children, 78(1), 7-23. https://doi.org/10.1177/001440291107800101

*Burns, M. K., Kanive, R., \& DeGrande, M. (2012). Effect of a computerdelivered math fact intervention as a supplemental intervention for math in third and fourth grades. Remedial \& Special Education, 33(3), 184191. https://doi.org/10.1177/0741932510381652

Butterworth, B., \& Yeo, D. (2004). Dyscalculia guidance. Nfer-Nelson Publishing Company.

Butterworth, B. (2003). Dyscalculia screener. Nfer-Nelson Publishing Company.

Butterworth, B. (2005). The development of arithmetical abilities. Journal of Child Psychology and Psychiatry, 46(1), 3-18. https://doi.org/10.1111/j.1469-7610.2004.00374.x 

ÖĞRENCILERIN AKADEMIK BAŞARILARINA ETKİSININ İNCELENMESI

Butterworth, B., Varma, S., \& Laurillard, D. (2011). Dyscalculia: From brain to education. Science, 332(6033), 1049-1053. https://doi.org/10.1126/science.1201536

Büyüköztürk, Ş., Akgün, Ö. A., Karadeniz, Ş., Demirel, F., \& Çakmak, E. K. (2017). Bilimsel araştırma yöntemleri [Research methods]. Pegem Akademi.

Card, N. A. (2011). Applied meta-analysis for social science research. The Guilford Press.

Chodura, S., Kuhn, J. T., \& Holling, H. (2015). Interventions for children with mathematical difficulties. Zeitschrift Für Psychologie, 223(2), 129-144. https://doi.org/10.1027/2151-2604/a000211

Copas, J., \& Shi, J. Q. (2000). Meta-analysis, funnel plots and sensitivity analysis. Biostatistics, 1(3), $247-262$. https://doi.org/10.1093/biostatistics/1.3.247

Cortiella, C., \& Horowitz, S. H. (2014). The state of learning disabilities: Facts, trends and emerging issues. National Center for Learning Disabilities. https://www.ncld.org/wp-content/uploads/2014/11/2014-Stateof-LD.pdf

Cowan, R., \& Powell, D. (2014). The contributions of domain-general and numerical factors to third-grade arithmetic skills and mathematical learning disability. Journal of Educaitonal Psychology, 106(1), 214229. https://doi.org/10.1037/a0034097

Dennis, M. S., Sharp, E., Chovanes, J., Thomas, A., Burns, R. M., Custer B., \& Park, J. (2016). A meta-analysis of empirical research on teaching students with mathematics learning difficulties. Learning Disabilities Research \& Practice, 31(3), 156-168. https://doi.org/10.1111/ldrp.12107

Emerson, J., \& Babtie, P. (2010). The dyscalculia assessment. Continuum.

*Faramarzi, S., \& Sadri, S. (2014). The effect of basic neuropsychological interventions on performance of students with dyscalculia. Neuropsychiatria i Neuropsychologia, 9(2), 48-54.

*Fien, H., Doabler, C. T., Nelson, N. J., Kosty, D. B., Clarke, B., \& Baker, S. K. (2016). An examination of the promise of the numbershire level 1 gaming intervention for improving student mathematics outcomes, Journal of Research on Educational Effectiveness, 9(4), 635-661. https://doi.org/10.1080/19345747.2015.1119229

Flanagan, D. P., \& Alfonso, V. C. (Eds.). (2010). Essentials of specific learning disability identification (Essentials of Psychological Assessment). John Wiley \& Sons.

Fletcher, J. M., Barth, A. E., \& Stuebing, K. K. (2011). A Response to intervention (RTI) approach to SLD identification. In D. P. Flanagan \& V. C. Alfonso (Eds.), Essentials of specific learning disability identification (pp. 115-145). John Wiley \& Sons.

Fletcher, J. M., Lyon, G. R., Fuchs, L. S., \& Barnes, M. A. (2006). Learning disabilities: From identification to intervention. Guilford Press.

*Flores, M. M., Hinton, V. M., \& Meyer, J. M. (2018). Teaching fraction concepts using the concreterepresentational-abstract sequence. Remedial and Special Education, 41(3), 165-175. https://doi.org/10.1177/0741932518795477

*Fuchs, L. S., Geary, D. C., Compton, D. L., Fuchs, D., Schatschneider, C., Hamlett, C. L., DeSelms, J., Seethaler, P. M., Wilson, J., Craddock, C. F., Braynt, J. D., Luther, K., \& Changas, P. (2013). Effects of first-grade number knowledge tutoring with contrasting forms of practice. Journal of Educational Psychology, 105(1), 58-77. https://doi.org/10.1037/a0030127

*Fuchs, L. S., Fuchs, D., Craddock, C., Hollenbeck, K. N., Hamlett, C. L., \& Schatschneider, C. (2008). Effects of small-group tutoring with and without validated classroom instruction on at-risk students' math problem solving: Are two tiers of prevention better than one? Journal of Educational Psychology, 100(3), 491-509. https://doi.org/10.1037/0022-0663.100.3.491

*Fuchs, L. S., Schumacher, R. F., Long, J., Namkung, J., Hamlett, C. L., Cirino, P. T., Jordan, N. C., Siegler, R., Gersten, R., \& Changas, P. (2013). Improving at-risk learners' understanding of fractions. Journal of Educational Psychology, 105(3), 683-700. https://doi.org/10.1037/a0032446 
Fuchs, L. S., Schumacher, R. F., Sterba, S. K., Long, J., Namkung, J., Malone, A., Hamlett, C. L., Jordan, N. C., Gersten, R., Siegler, R. S., \& Changas, P. (2014). Does working memory moderate the effects of fraction intervention? An aptitude-treatment interaction. Journal of Educational Psychology, 106(2), 499-514. https://doi.org/10.1037/a0034341

Geary, D. C, Hoard, M. K., Byrd-Craven, J., Nugent, L., \& Numtee, C. (2007). Cognitive mechanisms underlying achievement deficits in children with mathematics learning disability. Child Development, 78, 1343-1359. https://doi.org/10.1111/j.1467-8624.2007.01069.x

Geary, D. C. (1993). Mathematical disabilities: Cognitive, neuropsychological, and genetic components. Psychological Bulletin, 114(2), 345-362. https://doi.org/10.1037/0033-2909.114.2.345

Geary, D. C. (2011). Cognitive predictors of achievement growth in mathematics: A 5-year longitudinal study. Developmental Psychology, 47(6), 1539-1552. https://doi.org/10.1037/a0025510

Geary D. C. (2017). Dyscalculia at an early age. In R. E. Tremblay, M. Boivin, \& R. De. V. Peters (Eds.), Encyclopedia on early childhood development (online). http://www.child-encyclopedia.com/learningdisabilities/according-experts/dyscalculia-early-age

Geary, D. C., \& Hoard, M. K. (2005). Learning disabilities in arithmetic and mathematics: Theoretical and empirical perspectives. In J. I. D. Campbell (Ed.), Handbook of mathematical cognition (pp. 253-267). Psychology Press.

Geary, D. C., Hoard, M. K., Nugent, L., \& Bailey, D. H. (2010). Mathematical cognition deficits in children with learning disabilities and persistent low achievement: A five year prospective study. Journal of Educational Psychology, 104(1), 206-223. https://doi.org/10.1037/a0025398

Gerber, P. J. (2012). The impact of learning disabilities on adulthood: A review of the evidenced-based literature for research and practice in adult education. Journal of Learning Disabilities, 45(1), 31-46. https://doi.org/10.1177/0022219411426858

Gersten, R., Chard, D. J., Jayanthi, M., Baker, S. K., Morphy, P., \& Flojo, J. (2009). Mathematics instruction for students with learning disabilities: Meta-analysis of instructional components. Review of Educational Research, 79(3), 1202-1242. https://doi.org/10.3102/0034654309334431

Gifford, S. (2006). Dyscalculia: Myths and models. Research in Mathematics Education, 8(1), 35-51. https://doi.org/10.1080/14794800008520157

Gifford, S., \& Rockliffe, F. (2012). Mathematics difficulties: Does one approach fit all? Research in Mathematics Education, 14(1), 1-15. https://doi.org/10.1080/14794802.2012.657436

Gillum, J. (2014). Assessment with children who experience difficulty in mathematics. Support for Learning, 29(3), 275-291. https://doi.org/10.1111/1467-9604.12061

Girli, A. (2015). Öğrenme güçlüğü olan çocukların eğitimleri. S. S. Yıldırım-Doğru, (Ed.), Öğrenme güçlükleri [Learning Disabilities] içinde (ss. 227-232). Eğiten Kitap.

*Graham, L., Bellert, A., \& Pegg, J. (2007). Supporting students in the middle school years with learning difficulties in mathematics: Research into classroom practice. Australasian Journal of Special Education, 31(2), 171-182. http://dx.doi.org/10.1080/10300110701716477

Graham, S., \& Harris, K.R. (2009). Almost 30 years of writing research making sense of it all with the wrath of khan. Learning Disabilities Research \& Practice, 24(2), 58-68. https://doi.org/10.1111/j.1540$\underline{\text { 5826.2009.01277.x }}$

Güzel-Özmen, R. (2015). Öğrenme güçlüğü olan öğrenciler. İ. H. Diken (Ed.), Özel eğitime gereksinimi olan ögrenciler ve özel eğitim [Students with special education needs and special education] içinde (ss. 335361). Pegem Akademi Yayıncılık.

*Hellstrand, H., Korhonen, J., Linnanmäki, K., \& Aunio, P. (2019). The Number Race-computer-assisted intervention for mathematically low-performing first graders. European Journal of Special Needs Education, 35(1) 85-99. https://doi.org/10.1080/13488678.2019.1615792 

ÖĞRENCILERIN AKADEMIK BAŞARILARINA ETKİSININ İNCELENMESI

Higgins, J. P. T., \& Thompson, S. G. (2002). Quantifying heterogeneity in a meta analysis. Statistics in Medicine, 21(11), 1539-1558. https://doi.org/10.1002/sim.1186

*Huang, T., Liu, Y., \& Chang, H. (2012). Learning achievement in solving word-based mathematical questions through a computer-assisted learning system. Journal of Educational Technology \& Society, 15(1), 248259. http://www.jstor.org/stable/jeductechsoci.15.1.248

Huedo-Medina, T. B., Sanchez-Meca, J., Marin-Martinez, F., \& Botella, J. (2006). Assessing heterogeneity in meta-anlaysis: Q statistic or I2 index? Psychological Methods, 11(2), 193-206. https://doi.org/10.1037/1082-989X.11.2.193

Hughes, E. M., Witzel, B. S., Riccomini, P. J., Fries, K. M., \& Kanyongo, G. Y. (2014). A meta-analysis of algebra interventions for learners with disabilities and struggling learners. The Journal of the International Association of Special Education, 15(1), 36-47.

Jitendra, A. K., Lein, A. E., Im, S., Alghamdi, A. A., Hefte, S. B., \& Mouanoutoua, J. (2018). Mathematical interventions for secondary students with learning disabilities and mathematics difficulties: A metaanalysis. Exceptional Children, 84(2), 177-196. https://doi.org/10.1177/0014402917737467

*Jitendra, A. K., Dupuis, D. N., Rodriguez, M. C., Zaslofsky, A. F., Slater, S., Cozine-Corroy, K., \& Church, C. (2013). A randomized controlled trial of the impact of schema-based instruction on mathematical outcomes for third-grade students with mathematics difficulties. Elementary School Journal, 114(2), 252276. https://doi.org/10.1086/673199

Johnson, E., Mellard, D. E, Fuchs, D., \& McKnight, M. A. (2006). Responsiveness to intervention (RTI): How to do it. [RTI manual]. https://files.eric.ed.gov/fulltext/ED496979.pdf

*Kanive, R., Nelson, P. M., Burns, M. K., \& Ysseldyke, J. (2014). Comparison of the effects of computer-based practice and conceptual understanding interventions on mathematics fact retention and generalization, The Journal of Educational Research, 107(2), 83-89. https://doi.org/10.1080/00220671.2012.759405

*Kaufmann, L., Handl, P., \& Thöny, B. (2003). Evaluation of a numeracy intervention program focusing on basic numerical knowledge and conceptual knowledge. Journal of Learning Disabilities, 36(6), 564-573. https://doi.org/10.1177/00222194030360060701

Kaufmann, L., Mazzocco, M. M., Dowker, A., von Aster, M., Göbel, S. M., Grabner, R. H., Henik, A., Jordan, N. C., Karmiloff-Smith, A. D., Kucian, K., Rubinsten, O., Szucs, D., Shalev, R., \& Nuerk, H. C. (2013). Dyscalculia from a developmental and differential perspective. Frontiers in Psychology, 4, 1-5. https://doi.org/10.3389/fpsyg.2013.00516

Kirk, S., Gallagher, J., \& Coleman, M. R. (2017). Özel gereksinimli çocukların eğitimi [Educating exceptional children] (S. Rakap, Çev.; 14. baskı). Nobel Akademik Yayıncılık.

Kiru, E. W., Doabler, C. T., Sorrells, A. M., \& Cooc, N. A. (2018). A synthesis of technology-mediated mathematics interventions for students with or at risk for mathematics learning disabilities, Journal of Special Education Technology, 33(2) 111-123. https://doi.org/10.1177/0162643417745835

Krinzinger, H., \& Kaufmann, L. (2006). Rechenangst und rechenleistung. Sprache-Stimme-Gehör, 30(4), 160164. https://doi.org/10.1055/s-2006-951753

Kucian, K., \& von Aster, M. (2015). Developmental dyscalculia. European Journal of Pediatrics, 174(1), 1-13. https://doi.org/10.1007/s00431-014-2455-7

Küçükalkan, K., Beyazsaçlı, M., \& Öz, A. Ş. (2019). Examination of the effects of computer-based mathematics instruction methods in children with mathematical learning difficulties: A meta-analysis. Behaviour \& Information Technology, 38(9), 913-923. https://doi.org/10.1080/0144929X.2019.1597166

Lee, J., Bryant, D. P., Ok, M. W., \& Shin, M. (2020). A systematic review of interventions for algebraic concepts and skills of secondary students with learning disabilities. Learning Disabilities Research \& Practice, 35(2), 89-99. https://doi.org/10.1111/ldrp.12217

Li, Q., \& X. Ma. (2010). A meta-analysis of the effects of computer technology on school students' mathematics learning. Educational Psychology Review, 22(3), 215-243. https://doi.org/10.1007/s10648-010-9125-8 
Lipsey, M. W., \& Wilson, D. B. (2001). Practical meta-analysis. Sage Publications.

Maccini, P., Mulcahy, C. A., \& Wilson, M. G. (2007). A follow-up of mathematics interventions for secondary students with learning disabilities. Learning Disabilities Practice, 22(1), 58-75. https://doi.org/10.1111/j.1540-5826.2007.00231.x

Marita, S., \& Hord, C. (2016). Review of mathematics interventions for secondary students with learning disabilities. Learning Disability Quarterly, 40(1), 29-40. https://doi.org/10.1177/0731948716657495

Michaelson, M. T. (2007). An overview of dyscalculia: Methods for ascertaining and accommodating dyscalculic children in the classroom. Australian Mathematics Teacher, 63(3), 17-22. https://search.informit.com.au/documentSummary; $\mathrm{dn}=136592033316895 ;$ res=IELHSS

*Miller, S. P., \& Kaffar, B. J. (2011). Developing addition with regrouping competence among second grade students with mathematics difficulties. Investigations in Mathematics Learning, 4(1), 24-49. https://doi.org/10.1080/24727466.2011.11790308

*Mohd Syah, N. E., Hamzaid, N. A., Murphy, B. P., \& Lim, E. (2015). Development of computer play pedagogy intervention for children with low conceptual understanding in basic mathematics operation using the dyscalculia feature approach. Interactive Learning Environments, 24(7), 1477-1496. https://doi.org/10.1080/10494820.2015.1023205

Monei, T., \& Pedro, A. (2017). A systematic review of interventions for children presenting with dyscalculia in primary schools. Educational Psychology in Practice, 33(3), 277-293. https://doi.org/10.1080/02667363.2017.1289076

Mutlu, Y. (2016). Matematik öğrenme güçlüğü (gelişimsel diskalkuli). E. Bingölbali, S. Arslan \& İ. Ö. Zembat (Eds.), Matematik eğitiminde teoriler [Theories in mathematics education] içinde (ss. 881-899). Pegem Akademi.

Mutlu, Y., \& Akgün, L. (2017). Matematik öğrenme güçlüğünü tanılamada yeni bir model önerisi: Çoklu süzgeç modeli [A model proposal for diagnosis of mathematics learning difficulty: Multi-filter model]. İlkögrretim Online, 16(3), 1153-1173. https://doi.org/10.17051/ilkonline.2017.330247

Ok, M. W., Bryant D. P., \& Bryant, B. R. (2019). Effects of computer-assisted instruction on the mathematics performance of students with learning disabilities: A synthesis of the research. Exceptionality, 28(1), 3044. https://doi.org/10.1080/09362835.2019.1579723

Olkun, S. (2015). Matematik öğrenme güçlükleri. S. S. Yıldırım-Doğru (Ed.), Öğrenme güçlükleri [Learning difficulties] içinde (ss. 211-226). Eğiten Kitap.

Orwin, R. G., \& Vevea, J. L. (2009). Evaluating Coding Decisions. In H. Cooper, L. V. Hedges \& J. C. Valentine (Eds.), The handbook of research synthesis and meta-analysis (pp. 184-215). Russell Sage Foundation.

Öz, A. Ş. (2019). Bir özel eğitim kategorisi olarak öğrenme güçlükleri. E. R. Özmen \& A. Ataman (Ed.), Öğrenme güçlügü ve özel yetenek [Learning disability and special ability] içinde (ss. 1-24). Maya Akademi.

Özmen, E. R. (2014). Öğrenme problemleri: Önlenmesi ve düzeltilmesi, bir model önerisi [Learning problems: Prevention and correction. A model proposal], Yeni Türkiye Dergisi, 59, 1321-1332.

Özmen, E. R. (2018, 5-7 Şubat). Öğrenme güçlüğü olan çocukların tanımlanması, çeşitleri ve tanılanması [Identification, types and diagnosis of children with learning difficulties] [Seminer]. Dönem Arası Seminerleri 6, Orta Doğu Teknik Üniversitesi, Ankara, Türkiye.

Passolunghi, M. C., \& Lanfranchi, S. (2012). Domain-specific and domain-general precursors of mathematical achievement: A longitudinal study from kindergarten to first grade. British Journal of Educational Psychology, 82(1), 42-63. https://doi.org/10.1111/j.2044-8279.2011.02039.x

*Powell, S. R., Berry, K. A., \& Barnes, M. A. (2019). The role of pre-algebraic reasoning within a word-problem intervention for third-grade students with mathematics difficulty. ZDM Mathematics Education 52, 151163. https://doi.org/10.1007/s11858-019-01093-1 
*Re, A. M., Pedron, M., Tressoldi, P. E., \& Lucangeli, D. (2014). Response to specific training for students with different levels of mathematical difficulties. Exceptional Children, 80(3), 337-352. https://doi.org/10.1177/0014402914522424

Seo, Y., \& Bryant, D. P. (2009). Analysis of studies of the effects of computer-assisted instruction on the mathematics performance of students with learning disabilities. Computers \& Education, 53(3), 913-928. https://doi.org/10.1016/j.compedu.2009.05.002

Shin, M., \& Bryant, D. P. (2015). Fraction interventions for students struggling to learn mathematics. Remedial and Special Education, 36(6), 374-387. https://doi.org/10.1177/0741932515572910

Sterne, J. A. C., \& Egger, M. (2005). Regression methods to detect publication and other bias in meta-analysis. In H. R. Rothstein, A. J. Sutton \& M. Borenstein (Eds.), Publication bias in meta-analysis: Prevention, assessment and adjustments (pp. 99-110). John Wiley \& Sons.

Stevens, E. A., Rodgers, M. A., \& Powell, S. R. (2017). Mathematics interventions for upper elementary and secondary students: A meta-analysis of research. Remedial and Special Education, 39(6), 327-340. https://doi.org/10.1177/0741932517731887

Stultz, S. L. (2017). Computer-assisted mathematics instruction for students with specific learning disability: A review of the literature. Journal of Special Education Technology, 32(4), 210-219. https://doi.org/10.1177/0162643417725881

Sutton, A. J. (2009). Publication bias. In H. Cooper, L. V. Hedges, \& J. C. Valentine (Eds.), The handbook of research synthesis and meta-analysis (2nd ed., pp. 435-452). Russell Sage Foundation.

*Swanson, H. L., Lussier, C., \& Orosco, M. (2013). Effects of cognitive strategy interventions and cognitive moderators on word problem solving in children at risk for problem solving difficulties. Learning Disabilities Research \& Practice, 28(4), 170-183. https://doi.org/10.1111/ldrp.12019

Üstün, U., \& Eryılmaz, A. (2014). Etkili araştırma sentezleri yapabilmek için bir araştırma yöntemi: Meta analiz [A research method to make effective research syntheses: Meta analysis]. Eğitim ve Bilim, 39(174), 1-32. http://dx.doi.org/10.15390/EB.2014.3379

*Wang, A. Y., Fuchs, L. S., Fuchs, D., Gilbert, J. K., Krowka, S., \& Abramson, R. (2019). Embedding selfregulation instruction within fractions intervention for third graders with mathematics difficulties. Journal of Learning Disabilities, 52(4), 337-348. https://doi.org/10.1177/0022219419851750

Wei, X., Lenz, K. B., \& Blackorby, J. (2013). Math growth trajectories of students with disabilities: Disability category, gender, racial, and socioeconomic status differences from ages 7 to 17. Remedial and Special Education, 34(3), 154-165. https://doi.org/10.1177/0741932512448253

Wilson, D. B. (2009). Systematic coding. In H. Cooper, L. V. Hedges, \& J. C. Valentine (Eds.), The handbook of research synthesis and meta-analysis (2nd ed., pp. 159-176). Russell Sage Foundation.

Witzel, B. S., \& Little, M. E. (2016). Teaching elementary mathematics to struggling learners (1st ed.). The Guilford Press.

Xin, Y. P., \& Jitendra, A. K. (1999). The effects of instruction in solving mathematical word problems for students with learning problems: A meta-analysis. The Journal of Special Education, 32(4), 207-225. https://doi.org/10.1177/002246699903200402

Zheng, X., Flynn, L. J., \& Swanson, H. L. (2013). Experimental intervention studies on word problem solving and math disabilities: A selective analysis of the literature. Learning Disability Quarterly, 36(2), 97-111. https://doi.org/10.1177/0731948712444277 


$\begin{array}{cc}\text { Ankara University Faculty of } & \text { REVIEW } \\ \text { Educational Sciences Journal of } & \text { Recieved Date: } 02.04 .20 \\ \text { Special Education } & \text { Accepted Date: } 19.01 .21 \\ \text { OnlineFirst: } 29.01 .21\end{array}$

\title{
The Effects of Instructional Interventions on the Academic Achievement of Students with Mathematical Learning Difficulties
}

\author{
Tunahan Filiz $i$
}

\begin{abstract}
Introduction: The aim of this study is to make an up-to-date and detailed analysis by synthesizing different types of primary studies that examine the effect of instructional interventions for students with mathematical learning difficulties on academic achievement.
\end{abstract}

Method: Different types of studies that examine the effects of instructional interventions for students with mathematics learning difficulties on academic achievement were analyzed using meta-analysis method. The effect size values of the studies, the test of heterogeneity, publication bias and information about the moderator analysis were calculated using the CMA (Comprehensive Meta Analysis) statistical program.

Findings: The study revealed that intervention programs prepared for students with mathematical learning difficulties had a wide effect on the academic achievement levels of students (Hedge $g=0.764, \% 95 \mathrm{CI}=0.494$ $1.033)$.

Discussion: The overall effect size (0.764) obtained from the studies shows that instructional interventions have a positive effect on the mathematics performance of students with learning difficulties. It is seen that different instructional interventions have been developed in order to support these students. The instructional interventions support students in the process of learning mathematics, and continue to raise awareness on the learning difficulties. As a result, it can be stated that more instructional intervention studies are needed.

Keywords: Mathematics learning disabilities, dyscalculia, learning environment, instructional intervention, computer based instruction.

To cite: Filiz, T. (2021). The effects of instructional interventions on students with mathematical learning difficulties on students' academic achievement. Ankara University Faculty of Educational Sciences Journal of Special Education, 22(4), 1025-1055. https://doi.org/10.21565/ozelegitimdergisi.713496

${ }^{1}$ Lecturer, Bayburt University, tunahanfiliz@gmail.com, https://orcid.org/0000-0002-3149-8783 


\section{Introduction}

Mathematics learning difficulties involve issues regarding how to acquire the concept of numbers, memorize arithmetic facts, make accurate and fluent calculations and solve mathematical reasoning problems (American Psychological Association [APA], 2013). Although there is no exact data on the prevalence of mathematics learning disability, the rates differ from country to country. Uncertainties about how to identify and diagnose math learning difficulties may stem from these differences (Olkun, 2015). However, in different countries, this group constitutes approximately $5 \%$ of all children receiving education and $47 \%$ of all children (Cortiella \& Horowitz, 2014; Öz, 2019). Although this rate varies between 3\% and 14\% in different sources, it is stated by researchers that many more students have math learning difficulties (Bird, 2017). However, misdiagnosis may also have an effect on these high rates (Bender, 2016). Considering the importance of arithmetic skills and the rates of students with disabilities, supporting students with mathematics learning difficulties and coping with this situation emerges as an important issue. Math learning disability may not be overcome by students over time unless no intervention is implemented (Butterworth et al., 2011; Gerber, 2012). When the appropriate support is not provided, students develop negative attitudes about numbers and arithmetic. These negative attitudes can turn into math anxiety and a phobia directed towards the whole of school life (Krinzinger \& Kaufmann, 2006). For this reason, mathematical knowledge and skills should be developed in line with their potential by considering the individual differences and learning preferences of students who have math learning difficulties (Olkun, 2015).

Students who have math learning difficulties continue their education as full-time mainstreaming students in general education classes within the scope of special education. In addition, these students benefit from resource room and support education class services in mathematics lessons (Girli, 2015). When the studies on students who have math learning difficulties are examined, these students can learn mathematics even if they are not at the same speed and with the same methods as their typically-developing peers (Geary et al., 2010; Re et al., 2014). Students who have difficulty in learning mathematics are composed of students who learn slowly and differently. Due to the individual differences of students with learning disabilities, it is inevitable that the instructional strategies used to support these students will vary (Akçin, 2019; Kirk et al., 2017). There are widely used instructional strategies that support the learning-teaching process of students with learning disabilities. The effectiveness of these strategies has been proven (Akçin, 2019; Kirk et al., 2017). Research supports the use of teaching strategies such as explicit teaching, strategy teaching, direct teaching, metacognitive approach, and supportive teaching (Berkeley et al., 2010; Graham \& Harris, 2009; Maccini et al., 2007; Gersten et al., 2009).

Along with the meta analysis, it is aimed to expand the existing studies in the following ways. Firstly, this study presents an analysis of the experimental and quasi-experimental intervention studies published between 2003-2020. These intervention studies include up-to-date ones to meet the needs of students with math learning difficulties. Secondly, taking into account the fact that students with learning difficulties have a heterogeneous structure, together with the type of intervention, the effect sizes of the variables such as the students' level of education, diagnostic methods, mathematics learning area and duration of intervention were also calculated. Thirdly, under the heading of intervention type, effect sizes of computer assisted instruction, cognitive instruction, individualized education, direct education and evidence-based education were calculated. Fourth, by examining the education levels of students, students who have difficulties at primary and secondary levels were examined comparatively. In addition, with this study, the teaching components that form the basis of effective interventions for students who have learning disabilities were determined with the help of previous studies (Zheng et al., 2013). These teaching components are a guide for effective instructional interventions for students who have learning disabilities, especially for classroom teachers and other teachers. Meta analysis studies are considered important in terms of showing the tendency in the field and guiding the researchers who will work in the field. Finally, no study has been found in the national literature that demonstrates the effect of instructional interventions on the achievement of students who have math learning difficulties. Considering all these, the aim of the research is to identify effective instructional interventions prepared for students with mathematics learning difficulties, to guide teachers and researchers who will work in the field by synthesizing different types of primary studies examining the effects of these interventions on academic achievement.

\section{Method}

Meta analysis method was used in this study. This method allows to reach more generalized and verified results by combining the results obtained from studies with similar or related purposes (Arthur et al., 2001; Büyüköztürk et al., 2017). For this reason, the studies to be included in the meta-analysis study should contain statistical findings (Büyüköztürk et al., 2017). In general, meta-analysis studies are carried out to test whether the 
relationship between the effect size values of the studies is heterogeneous, to determine the confidence interval and statistical significance of the effect size of the relationship examined, and to determine possible variables that cause the result of heterogeneity between studies (Huedo-Medina et al., 2006).

\section{Purpose of the Study, Problem and Dependent/Independent Variable}

The aim of this study is to create a prepare and comprehensive meta-analysis study by synthesizing the primary studies examining the effect of intervention programs for students with math disabilities (MD) on their academic achievement. Experimental and quasi-experimental studies examining intervention programs designed to improve students' academic achievements were examined under meta-analysis. In the different studies where the intervention programs were independent variables; the type of intervention, the identification and duration of the implementation, the sample size, the mathematics skills and the grade level where the intervention was carried out were the study variables. This study answered the following questions:

1. What is the effect of intervention programs prepared for students with math learning disabilities on students' academic achievements?

2. What is the difference between the effect sizes of studies based on the type of intervention used in teaching mathematics?

3. What is the difference between the effect size of the studies according to the criteria used in the identification of the students?

4. Do the effect size values of the studies lead to a significant difference according to the mathematics learning areas?

5. What is the difference between the effect size of the studies according to the grade level?

6. Is the difference between the effect sizes of the studies significant according to the duration of the intervention?

\section{Data Collection}

After determining the purpose and problem of the research, the databases were scanned. For this purpose, Academic Search Complete, Educational Resorces Information Center (ERIC), Science Direct, Springer Link, Taylor \& Francis Online, Scopus, ULAKBIM National Databases (UVT), Web of Science, Sage Journals, Wiley Online Library Full Collection and Google Scholar databases were utilized. In addition, the following journals were scanned manually: Exceptional Children, Journal of Individual Differences, Journal of Learning Disabilities, Journal of Special Education, Learning Disabilities Research and Practice, Learning Disability Quarterly, Remedial and Special Education and The Elementary School Journal. As a result, 562 articles were reached. The keywords in the following were utilized: Mathematics learning difficulty/disability, dyscalculia, learning difficulties, learning environment, learning environment design, intervention or treatment, mathematics education, mathematical interventions, at risk. As a result, 76 studies were identified.

\section{Inclusion Criteria}

The quality of the studies included in the meta-analysis is seen as one of the important points affecting the outcome. Therefore, the inclusion criteria are considered important in the preparation of meta-analysis. The inclusion criteria are in the following:

1. Studies provided teaching, intervention or improvement dealing with academic skills for students with math learning difficulties,

2. In the intervention studies, the participants were school-age students and the students with math learning difficulties. The participants were clearly defined by the researchers,

3. Experimental group or semi-experimental group methods used in the studies with the control group,

4. The study included information that allowed the calculation of effect sizes,

5. The reviewed studies were published in refereed journals and written in English,

6. Studies were published between 2003-2020.

In the study, the studies meeting the inclusion criteria were included. Those not belonging to any math learning areas where statistical information was not obtained were not included in the meta-analysis study. As a result of this review, 24 studies were included in the study. 


\section{Coding Process and Validity/Reliability Studies}

The studies were coded using the form prepared by the researcher. In the first part of the form, descriptive information about the study (name, type of publication, author/authors, place of study, sample size, corresponding author and time of publication) was included. In the second part, explanatory information about the study (diagnostic criteria, type of intervention, education level, duration of intervention and learning area) was included. In the last section, quantitative data (sample size, mean, standard deviation) belonging to the control and experimental group required in the effect size calculations were included.

For the validity analyses related to the coding form, two experts (one Special Education expert and the other on the Mathematics Education) were asked to evaluate the studies in terms of clarity, comprehensibility and coverage. Expert opinion form was prepared as 5-point Likert type: Absolutely appropriate (5), appropriate (4), undecided (3), not suitable (2) and absolutely not suitable (1). In line with this information, the coding form was finalized. The responses were processed into a form created electronically. There needed to be transparency that allowed critical evaluations in coding processes and repeatability, which was reported to reveal the accuracy of primary studies (Wilson, 2009).

Another important issue in meta-analysis studies was to ensure reliability. Coding reliability consisted of two dimensions. The first was encoder reliability referring to the coding consistency of an encoder. The second was intercoder reliability that expressed consistency between different encoders (Lipsey \& Wilson, 2001). Accordingly, the study was evaluated by at least two people in order to ensure reliability between coders. In smallscale meta-analysis studies where the number of studies is limited, binary coding is generally performed. In largescale meta-analysis studies where the number of studies is high, random sampling method is used (Wilson, 2009). As this research was a small-scale meta-analysis study, binary coding was preferred.

This study, different procedures were utilized to provide coding reliability. First, studies were coded to be directed to the expert opinion. Second, reliability between independent coders was calculated. Then, using the compromise rate, the consistency between two independent coders was revealed. The compromise rate can be used to measure reliability between coders (Orwin \& Vevea, 2009). This ratio is obtained by proportioning the number of views agreed upon to the total opinion. For this study, the reliability value between the coders was calculated as an average of 0.94 , with a minimum of 0.90 and a maximum of 0.98 .

\section{Findings, Discussion and Conclusion}

The effect size value for all the studies were calculated as 0.764 . This value indicated that instructional interventions (cognitive instruction, direct instruction, computer-assisted instruction, individualized instruction, and evidence-based instruction) had a positive effect on the mathematics performance of students with math learning difficulties. This finding was similar to previous studies (Dennis et al., 2016; Jitendra et al., 2018; Küçükalkan et al., 2019; Stevens et al., 2017). How the effect sizes affected different variables was another issue that needed to be taken into account as studies differed in variables such as type of intervention, diagnostic criteria, learning area, educational levels, and duration of the intervention.

\section{Type of Intervention}

Effect size values obtained from studies differed significantly according to the type of intervention. When the findings regarding the type of intervention were examined, it was seen that the effect size value of the neuropsychological intervention was quite high. Another result of this variable was that concrete-representationabstract teaching, self-regulation instruction, fraction intervention program, individualized instruction, schemabased instruction, and enhanced anchored instruction had a high effect on the instruction of students with mathematics learning difficulties. These results were supported by various studies in the literature (Chodura et al., 2015; Gersten et al., 2009; Marita \& Hord, 2016; Monei \& Pedro, 2017). Computer based instruction was another variable that had an impact on the formation of this significant difference. Computer based instruction had a moderate effect on the instruction of students with mathematics learning difficulties. Previous studies supported this result (Chodura et al., 2015; Jitendra et al., 2018; Küçükalkan et al., 2019; Li \& Ma, 2010; Stevens et al., 2017; Stultz, 2017). It was seen that different instructional interventions were developed in order to support students with mathematics learning difficulties. However, when challenges persisted despite these interventions, the next intervention steps were not clear (Gillum, 2014). However, the instructional intervention supported students in the mathematics teaching process and continued to raise awareness on mathematics learning difficulties (Monei \& Pedro, 2017). 


\section{Identification}

Identifying students with math learning difficulties at an early age and developing and implementing individual instructional intervention are important for mathematics teaching. However, there is no agreed approach in both the definition and the diagnosis of mathematics learning disability. When the different views and approaches regarding the diagnosis are examined, it can be stated that they cannot provide sufficient data for the instructional interventions to be prepared for individuals. Studies indicate that a detailed diagnosis can also guide a properly focused intervention (Ashlock, 2015; Kaufmann et al., 2013).

It is stated that diagnostic practices and access to special education services suitable for the individual characteristics of these students are not yet sufficient in Turkey (Özmen, 2014). Lack of adequate measurement tools for diagnosis can be seen as an important factor in the emergence of this situation. In a way, students are diagnosed with psychological process evaluation with intelligence and perception tests used in the medical diagnosis. There are inconsistencies in diagnosis as medical and education diagnosis cannot be combined. Inconsistencies in the diagnosis cause a child to be diagnosed with mental disability for one year and diagnosed as learning disability in the next year or vice versa, and students without learning difficulties to be diagnosed as learning difficulties (Özmen, 2018). The fact that learning disability is a group that is difficult to diagnose and the students in this group exhibit different characteristics. In addition to the formal assessment (ability and achievement test) results, classroom evaluations including criterion-referenced tests, curriculum-based assessment and observation are required.

\section{Mathematics Skills}

When the results of the moderator analysis of the mathematics learning area are examined, it is concluded that the instructional interventions do not make a significant difference according to the mathematics learning areas. In addition, it was obtained that the effect size values related to learning areas including fractions and number information had a high effect value. The effect size value related to algebra learning area had a weak effect. This result is similar to the results of Stevens et al. (2017) and Dennis et al. (2016). When the data on mathematics learning areas are examined, it is seen that intervention programs generally focus on the learning area entitled the perception of numbers. The fact that the studies included in the research are usually at primary school level. Considering that basic arithmetic skills are the basis of other skills, this result may not be surprising. In addition, it was observed that the effect size values related to learning areas were high in all learning areas. Therefore, it can be stated that the instructional intervention programs affect student achievement in the context of math learning area. The only learning area with a weak effect size is the algebra learning area. The results obtained in the field of algebra learning seem to contradict with the literature (Lee et al., 2020; Stevens et al., 2017). In the emergence of this difference, the studies included in the meta-analysis were observed to examine different teaching components. More work can be done with different teaching components related to the field of algebra learning. In addition, the studies target a certain content area. Students cannot respond to intervention programs targeting a specific content area due to the inadequacy of skills on that topic (Stevens et al., 2017). Therefore, it can be considered important to search for intervention programs targeting more than one skill area.

\section{Grade Level}

When the effect size values of the education level are analyzed, it is concluded that the instructional interventions developed for students with mathematics learning difficulties do not differ significantly in the context of the education level. In addition, when the effect size values of the education level were examined, it was seen that the effect size value of the secondary school level was high, although the values were close to each other. Our conclusion is not consistent with the literature. Research suggests that interventions will have a stronger impact on elementary school students as the level of mathematics content will increase as the level of teaching increases (Chodura et al., 2015; Gersten et al., 2009; Jitendra et al., 2018). This might stem from the methodological features of the studies included in the research. Another important result is that the number of mathematical intervention programs implemented at the primary school level is more than those in the secondary school. The high number of intervention studies conducted at primary school may be due to the importance of early intervention and diagnosis.

\section{Duration of Intervention Program}

The results obtained from the moderator analysis regarding the duration of the intervention program demonstrate that the duration of the intervention does not make a significant difference on student achievement. The results show that medium and short-term sessions have a higher impact than long-term sessions. In the 
emergence of this situation, the limited number of studies included in the study and the examination of more studies at primary level can be cited as a reason. Research results reveal that students should be included in the intervention for a long time especially in teaching higher level mathematical skills (Jitendra et al., 2018). Increased intensity and content within the intervention programs for students with mathematics learning difficulties provide an increase in the mathematics performance of these students (Bryant et al., 2008; Stevens et al., 2017).

\section{Limitations and Future Directions}

The meta-analysis study has some limitations. There are some suggestions for future research. Firstly, 24 experimental and semi-experimental studies were included in this meta-analysis study, which examined the last 17 years (2003-2020). This number is relatively limited compared to reading intervention programs. Future studies may focus on more effective mathematical intervention studies for students with math learning difficulties, given the importance of mathematics (Hughes et al., 2014). In addition, generalizations with the results obtained from semi-experimental studies cause possible limitations. It can be stated that there is a need to do more research with larger samples about which instructional intervention is more effective on students with math learning difficulties.

Secondly, only experimental and quasi-experimental studies were included in the analysis. Numerous single-subject studies examining the effectiveness of intervention programs prepared for students with math learning difficulties in line with our selection criteria were not included in the study. In addition, only article-type studies were included in our synthesis. In order to eliminate these limitations, studies with a broad sample can be conducted. These studies should include various research types (prepared in the format of thesis, papers, etc.) including single-subject studies. Thirdly, the criteria used to evaluate and identify students with mathematics learning difficulties should be reviewed. In the studies conducted, in-class evaluations can be used together with formal evaluations such as formal screening tests, ability and achievement tests in identifying students with mathematical learning difficulties. 